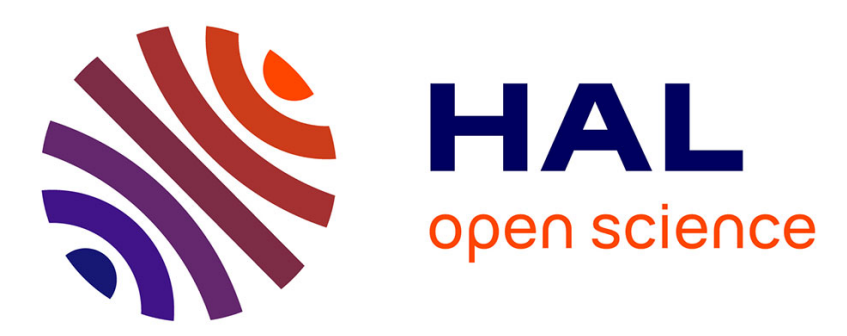

\title{
Threading the weft, testing the warp: population concepts and the European Upper Paleolithic chronocultural framework
}

Natasha Reynolds

\section{To cite this version:}

Natasha Reynolds. Threading the weft, testing the warp: population concepts and the European Upper Paleolithic chronocultural framework. 2020. hal-02463093

\section{HAL Id: hal-02463093 \\ https://hal.science/hal-02463093}

Preprint submitted on 31 Jan 2020

HAL is a multi-disciplinary open access archive for the deposit and dissemination of scientific research documents, whether they are published or not. The documents may come from teaching and research institutions in France or abroad, or from public or private research centers.
L'archive ouverte pluridisciplinaire HAL, est destinée au dépôt et à la diffusion de documents scientifiques de niveau recherche, publiés ou non, émanant des établissements d'enseignement et de recherche français ou étrangers, des laboratoires publics ou privés. 
Manuscript version of: Reynolds, N. (in press). Threading the weft, testing the warp: population concepts and the European Upper Paleolithic chronocultural framework. In: H.S. Groucutt (Ed.), Culture History and Convergent Evolution: Can we Detect Populations in Prehistory? Springer, Cham, Switzerland. https://doi.org/10.17605/OSF.IO/7BU95

\title{
Threading the weft, testing the warp: population concepts and the
} European Upper Paleolithic chronocultural framework

\author{
Natasha Reynolds \\ natasha.reynolds@u-bordeaux.fr
}

UMR 5199 PACEA, Université de Bordeaux, Bâtiment B2, Allée Geoffroy Saint Hilaire, CS 50023, 33615 PESSAC CEDEX, France.

\begin{abstract}
:
Interpretations of the European Upper Paleolithic archaeological record have long relied on concepts of past populations. In particular, cultural taxonomic units - which are used as a framework for describing the archaeological record - are commonly equated with past populations. However, our cultural taxonomy is highly historically contingent, and does not necessarily accurately reflect variation in the archaeological record. Furthermore, we lack a secure theoretical basis for the inference of populations from taxonomic units. In order to move past these problems and satisfactorily address questions of Upper Paleolithic
\end{abstract}


populations, we need to entirely revise our approach to chronocultural framework building. Here, I outline a specific way of describing the archaeological record that deliberately avoids the use of cultural taxonomic units and instead concentrates on individual features of material culture. This approach may provide a more appropriate basis for the archaeological study of Upper Paleolithic populations and for comparison with genetic data.

Keywords: cultural taxonomy, genetics, Aurignacian, Gravettian, Magdalenian

\section{Running head: The European Upper Paleolithic}

\section{Introduction}

The European Upper Paleolithic represents a special case in the study of past populations within the Paleolithic archaeological record. Leaving aside questions concerning the authorship of the "transitional" industries (Hublin 2015), the European Upper Paleolithic relates, as far as we know, to a single hominin taxon: Homo sapiens. This is in contrast with many other parts of the Paleolithic archaeological record, where multiple taxonomically distinct hominin groups need to be considered. Furthermore, the Upper Paleolithic archaeological record of Europe is abundant and relatively well-studied, and we have extensive associated data on ancient human genomes in comparison with other parts of the world.

However, the Upper Paleolithic populations of Europe remain poorly understood archaeologically. There is little agreement on what archaeology can tell us about Upper Paleolithic populations: we lack consensus or even much explicit discussion concerning the 
definition of populations, an epistemological framework, the formulation of research questions, and the methods and theoretical approaches we might employ.

Population concepts are often used in studies of the Middle to Upper Paleolithic transition, where the Middle Paleolithic is associated with a Neanderthal population and the Upper Paleolithic with an anatomically modern human population: here, usage of the population concept is generally quite clear and in line with biological understandings of the term. There has also been substantial research into Upper Paleolithic demography, again usually demonstrating a clear understanding of population concepts in the biological sense (e.g. Bocquet-Appel and Demars 2000; Gamble et al. 2005; French 2015; Tallavaara et al. 2015).

However, population concepts are also widely invoked as explanations for variation within the Upper Paleolithic archaeological record. For example, as we shall see below, the differences between lithic assemblages in two regions might be explained by the idea that different populations were present in each area at some point in the past. In these cases, the word seems to be used without a formal definition, meaning, essentially, "a group of people". However, it usually appears to refer to a group of people posited to have been linked by common cultural traditions as well as perhaps common ancestry and/or identity.

Population concepts are closely linked with one of our most important analytical approaches to the Upper Palaeolithic: cultural taxonomy. Cultural taxonomy concerns the definition and description of archaeological taxonomic units (e.g. Aurignacian, Badegoulian, Ahrensburgian). These might be called "technocomplexes", "archaeological cultures", etc, and archaeologists vary strongly in how they use these concepts (e.g. Clarke 1968; Dunnell 1971; Gamble et al. 2005; Clark and Riel-Salvatore 2006; Roberts and Vander Linden 2011; Sørensen 2014; Hermon and Nicolucci 2017; Reynolds, accepted manuscript). Taxonomic units, established based on the study of material culture and chronology, are frequently 
postulated to have been associated with particular past "populations". Depending on the example, this population may be more or less explicitly defined, more or less discrete, and more or less persistent. Populations are often described based on the existence of taxonomic units, and are often named after them: hence e.g. "the Gravettians", "the Solutreans", etc.

For better or worse, the study of the Upper Paleolithic never had a backlash against ideas of "stone tools equal people" to the degree that the study of later prehistory in the West took a turn against ideas that "pots equal people" (Kramer 1977; Van Oyen 2017). Many archaeologists appear comfortable with, for example, thinking of a group of people called "the Aurignacians", distinct in their traditions, ancestry and identity, who made and deposited the archaeological assemblages that we now call Aurignacian. Furthermore, archaeologists might think of these people as clearly different from "the Gravettians" who apparently succeeded them. These ideas may be explicitly stated and meant literally, or they may be hidden assumptions or used as heuristic tools.

In this chapter I discuss several aspects of the continuing importance of population concepts in the study of the Upper Paleolithic and how they manifest themselves as part of the chain of reasoning that leads us from collections of excavated artefacts to the re-creation of social and cultural processes during the Late Pleistocene. I begin with a discussion of some explicit uses of the population concept in Upper Paleolithic archaeological interpretation. I then discuss the present cultural taxonomic system and some of its shortcomings, in order to argue that taxonomic units should not be naïvely correlated with past populations. In an attempt to create a better basis for the archaeological understanding of late Pleistocene populations, I devote the middle part of this chapter to advocating a specific way of building and revising the Upper Paleolithic chronocultural framework, based on an emphasis on coherence and a dialectical consideration of chronological and material culture data. I also outline a specific way of conceptualizing this framework, which focuses not on the construction of abstract 
taxonomic units, but rather on describing multiple links between assemblages based on the co-presence of index fossils or other well-defined features. I then discuss our prospects for establishing a robust archaeological approach to populations by comparing the chronocultural framework against the results obtained from paleogenetic studies. Although at present we are far from being able to make reliable inferences about Upper Paleolithic populations from the archaeological record, there is much potential for future progress.

\section{Populations in the European Upper Paleolithic}

The use of population concepts in the study of the Upper Paleolithic, particularly as expressed in references to "the Aurignacians", "the Gravettians", etc., has a long history. The early twentieth century history of these concepts also demonstrates - although a full treatment of this subject is beyond the scope of the current paper - their development in a context of essentialist and often racist approaches to populations and ethnic groups (see e.g. MacCurdy 1914, 1915; Macalister 1921: 385; Hřdlicka 1927; Collie 1928; Burkitt and Childe 1932; cf. McNabb, this volume). The prejudices that shaped archaeological concepts during this time may have had more influence than we would like to think on modern archaeological ideas of Paleolithic populations and may go some way towards explaining their deficiencies.

To gain an impression of some ideas that were in circulation and without repeating here the more odious racist comparisons, we can consider the following quotation from Macalister (1921, p. 580-2): "One of the most difficult problems of the Upper Paleolithic Term is the relation of the Solutreans to the Aurignacians which preceded them, and to the Magdalenians which followed them. ... That the Solutrean culture is associated with a people of different racial affinities from the Aurignacian is indicated by the bones from Předmost and Brünn. ... Some circumstances drove the Solutreans back from central and eastern Europe along the way by which their ancestors had come. They crowded back on the Aurignacians and for a 
time kept them suppressed." Similarly, Burkitt and Childe (1932: 192) state that "The Solutreans invaded parts of Western Europe and dominated the Aurignacians." From these quotations we can see that archaeological cultures were seen as being the product of groups of people named for them, and these groups of people were seen as discrete populations or ethnic groups whose histories of migration and development could be reconstructed. The descriptions of postulated interactions between past populations using a vocabulary of invasion, suppression or domination, and the notions of essential "racial" difference between them, now seem clearly of their time. However, ideas concerning the existence of "Solutreans", "Aurignacians" etc. have been passed down to us in the present day and continue to live on in archaeological discussions. Although the language used has typically been toned down to more neutral terminology of "population replacement" etc, we shall see that notions of essential differences between "Solutreans", "Magdalenians" etc still permeate much archaeological interpretation in the present day, despite the lack of convincing archaeological or genetic evidence for such discrete populations.

Although not all modern archaeologists refer to populations in the Upper Paleolithic with respect to cultural groupings, many do so explicitly. Reference to "Aurignacians", "Gravettians" etc. is still fairly common in modern archaeological practice (e.g. Bodu 1998; Finlayson and Carrión 2007; Otte 2010, 2013; Ronchitelli et al. 2015; Svoboda 2015; Tejero, 2016), even if the intended meaning of these terms varies between authors. Some go further, and link changes in the archaeological record with putative population extinctions and movements in the past (e.g. Gamble et al. 2005; Banks et al. 2008; Schmidt et al. 2012; Kozłowski 2015; Djindjian 2016). For example, it has been explicitly argued that the population that created Aurignacian assemblages went extinct and was replaced by another population that created Gravettian assemblages (Finlayson and Carrión 2007, Bradtmöller et al. 2012), and, on a different scale, that the appearance of Badegoulian assemblages in France 
represents a population incursion from Central Europe (Gamble et al. 2005; cf. Banks et al. 2008).

Of course, the idea that movements of populations are responsible for changes in the archaeological record is itself logically dependent on the idea that distinct populations coexisted during the Upper Paleolithic. One modern example of this is the idea that the Epigravettian and Magdalenian, or Epigravettian and Solutrean, technocomplexes are evidence for distinct contemporary populations during the Late Upper Paleolithic (Banks et al. 2008; Bradtmöller et al. 2012). However, in many other cases the idea of the co-existence of separate populations is not discussed directly, especially where work is focused on diachronic change within small regions. Rather, the idea that discrete populations co-existed during the Upper Paleolithic (either within Europe or in a larger geographic area) is an assumption implicit within the argument for the replacement of one population by another.

\section{Upper Paleolithic cultural taxonomy}

As we have already seen, explicit discussions of populations are usually framed around named cultural taxonomic units (or "technocomplexes", "archaeological cultures", etc), i.e. taxonomic units are seen to correspond to past populations. But what are these taxonomic units and how robust is the inference of populations from them? Understandings of cultural taxonomy among Upper Paleolithic archaeologists are highly diverse (e.g. Djindjian et al. 1999; Gamble et al. 2005; Clark and Riel-Salvatore 2006; Riede 2011; Reynolds, accepted manuscript), and the strength of the theoretical and empirical foundations of these understandings similarly differs strongly. In practice, these units can be treated as time periods, as sets of assemblages, as past populations, as traditions or sets of traditions, as geographical distributions, as combinations of all these things, or as different things at

different times (Reynolds, accepted manuscript). Archaeologists usually do not think of all 
these units in the same way, and might think about "the Gravettian" differently than "the Badegoulian", and "the Ahrensburgian" differently than "the Aurignacian", if only because their temporal and geographical scales differ. Nevertheless, most archaeologists work on the assumption that these units are to some extent meaningful and useful in describing the structure of the archaeological record of Upper Paleolithic Europe.

The following is a brief and partisan summary of the status of these major taxonomic units as they are currently used. The earliest "transitional" Upper Paleolithic industries in Europe remain enigmatic and heavily disputed regarding their association with Neanderthals and/or anatomically modern humans (Hublin 2015). "Proto-Aurignacian" assemblages appear to relate to a distinct chronological phase, earlier than "Aurignacian" assemblages sensu stricto (Le Brun Ricalens et al. 2009; Teyssandier et al. 2010; Bordes et al. 2011; Banks et al. 2013a, 2013b). Numerous chronologically restricted types of Aurignacian assemblages can be identified in various parts of Europe based on lithic and osseous evidence (especially the presence/absence of index fossils such as burins busqués); examples include the Early Aurignacian and Evolved Aurignacian groups in Western Europe (e.g. Noiret 2009; Michel 2010; Sinitsyn 2010; Bordes et al. 2011; Anghelinu and Niţă 2014; Chu et al. 2018). The situation concerning Gravettian assemblages is rather similar, in that numerous Gravettian faciès are described for different time periods and areas based on assemblage contents, particularly the presence of particular index fossils: our knowledge of these across Europe is perhaps better than for Aurignacian assemblages, and examples include the Rayssian, Noaillian and Kostënki-Avdeevo Culture groups (e.g. Klaric 2007; Noiret 2009; de la Peña and Vega Toscana 2013; Noiret 2013; Pesesse 2013; Reynolds 2014; Lengyel 2016). For later periods, the situation becomes more complicated. In parts of Western Europe, Solutrean and Badegoulian assemblages post-date Gravettian assemblages, which in turn are post-dated by Magdalenian assemblages (Straus 2000; Ducasse and Langlais 2007; Renard 2011; 
Ducasse 2012; Langlais et al. 2016). However, in much of Eastern, Central and Southern Europe, where Solutrean assemblages have not been identified, Late Upper Paleolithic assemblages post-dating Gravettian assemblages may be described as Epigravettian, Magdalenian or Epiaurignacian (Burdukiewicz 2001; Svoboda and Novák 2004; Verpoorte 2009; Maier 2015). The latest Upper Paleolithic assemblages in Europe have been attributed to a multiplicity of taxonomic units including Azilian, Hamburgian, and Swiderian (e.g. Grimm and Weber 2008; Burdukiewicz 2011; Fat Cheung et al. 2014; Sauer and Riede 2018). However, the validity of the distinctions between many of the Late and Final Upper Paleolithic taxonomic units is in fact rather questionable (Svoboda and Novák 2004; Maier 2015: 236-237, Naudinot et al. 2017; Sobkowiak-Tabaka and Winkler 2017; Sauer and Riede 2018). Finally, some geographically restricted taxonomic units, especially in Eastern Europe (e.g. Streletskian, Gorodtsovian) have resisted inclusion into the main European chronocultural framework and their significance remains difficult to understand (Sinitsyn 2010, 2015).

Much archaeological research continues to be carried out on an assumption of the robusticity and essentiality of these units and the differences between them. However, our taxonomic units are not mutually equivalent in their salience, their temporal and geographical scope, or the amount of material culture variation they incorporate. The major taxonomic units (Aurignacian, Gravettian, Magdalenian, Epigravettian) relate to many thousands of years and huge geographical areas, subsuming a significant amount of variation in material culture, subsistence practices, mobility patterns, and so on. Although each of these groups are, in principle, united by certain aspects of their material culture, and relate to coherent periods of time and contiguous geographical areas, as outlined above the fact of internal variation and phasing within each of these taxonomic units is extremely well-established. On the other hand, the distinctions between many taxonomic units are questionable, and there may be 
significant continuity in material culture variability between groups of assemblages conventionally attributed to different units. This includes similarities between units that are separated chronologically (e.g. Gravettian and Epigravettian: Mihailovic and Mihailovic 2007; Anghelinu et al. 2018) and between those that are separated geographically (e.g. the numerous Late Upper Paleolithic industries of Central Europe: Sobkowiak-Tabaka and Winkler 2017; Sauer and Riede 2018).

As is widely understood, the existing system of units has developed historically and is far from systematically constructed. Certain regions (especially, of course, Aquitaine) have been far more important for the construction of units than others, and the taxonomic units originally defined based on Aquitanian material have been subsequently applied across Europe (e.g. Otte 1981; Noiret 2009; Sinitsyn 2015). Political factors and nationalist frameworks have heavily shaped the system of taxonomic units that we use (Tomášková 2003; Vander Linden and Roberts 2011; Sauer and Riede 2018). Quite aside from the complex history of development of the taxonomic framework, the nature of the archaeological record itself does not always lend itself easily to the systematic definition of equivalent units. Some parts of the Upper Paleolithic are more obviously distinctive in their surviving material culture than others, which may or may not reflect past cultural distinctiveness. Furthermore, the heterogeneous geology of Europe has created great variation in depositional contexts. Short-term open-air sites in Eastern Europe present very different challenges and opportunities for defining taxonomic units than do dense cave sequences from further west. Finally, of course, even if we can obtain a full understanding of the archaeological record and its history of interpretation, the definition of taxonomic units from first principles is by no means a settled matter (e.g. Clarke 1968; Dunnell 1971; Gamble et al. 2005; Clark and Riel-Salvatore 2006; Riede 2011; Shea 2014). 
Given the known problems with the cultural taxonomic framework as it currently exists, it is clearly inappropriate to equate cultural taxonomic units with past populations. In some cases, there may have been population continuity between chronologically or geographically distinct taxonomic units; in others, taxonomic units may subsume multiple distinct prehistoric populations. Cultural taxonomic units, at whatever scale, should not be treated as representing discrete, monolithic cultural phases; nor should they be correlated with discrete, distinctive past populations.

However, this critique of the cultural taxonomic framework should not be taken to question the existence of clear patterning within the Upper Paleolithic archaeological record. Similarities and differences between sites and assemblages do often reflect past sociocultural relationships, and these can be used to examine questions of population dynamics in the Upper Paleolithic. But in order to start addressing questions of population dynamics more accurately, we need to find a better approach to building and conceptualizing our chronocultural framework. In the following sections I want to explicitly outline one particular approach to chronology and material culture comparison that can be used across the European Upper Paleolithic record. Most of this is not new, and my version of this approach is built on the work of numerous other researchers (e.g. Garrod 1938; Rogachëv 1957; de Sonneville Bordes 1966; Otte 1981; Demars and Laurent 1992; Grigor'ev 1993; Bordes 2006; Le Brun-Ricalens et al. 2009; Klaric et al. 2009; Noiret 2009; Teyssandier and Zilhão 2018). However, since this kind of approach is not universally used or understood, I think it is worth describing it explicitly. 


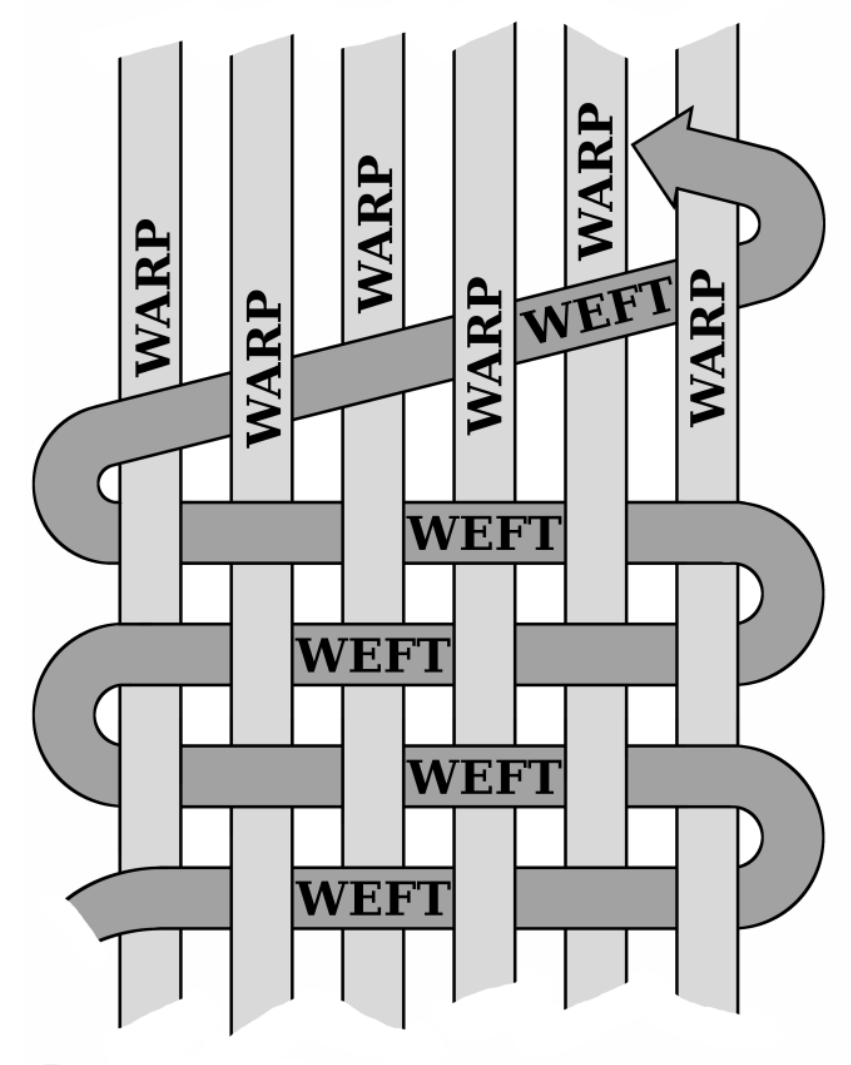

Fig. 1: Warp (chronology) and weft (material culture comparisons).

\section{The European Upper Paleolithic chronocultural framework: warp and} weft

A large part of the history of progress in European Upper Paleolithic studies is a history of improved understanding both of the chronology and sequencing of assemblages (what I refer to in this chapter as the "warp") and of intra- and inter-regional comparisons based on material culture (the "weft") (Fig. 1). Together this knowledge can be combined to form what we can call the chronocultural framework of Upper Paleolithic Europe: an overview of the material variability of the archaeological record in its chronological and geographical framework. I have deliberately chosen this warp and weft analogy because it helps to 
illustrate a fundamental point: in the approach I am outlining here, there is an assumption that there is a certain underlying regularity to the archaeological record that can and should be used to help us synthesize our understanding, and that both chronological and material culture evidence should be used dialectically. Where artefact or assemblage types are well-described, they often cluster in time and space, even if the scale of the clusters varies depending on the aspect of material culture we are examining. Some aspects of material culture were highly persistent, lasting for thousands of years; others were far more ephemeral. Some material culture features have been found across Europe; others have only been found in limited regions. The temporal and geographical restriction of certain features is what allows us to construct a useful chronocultural framework for Upper Paleolithic Europe.

This type of work remains utterly essential to archaeological practice: we have no hope of understanding complex processes such as population dynamics, the spread of technologies, or responses to environmental changes, without comprehensive knowledge of what material culture variability looks like. It should be noted from the outset that I count the construction of taxonomic units as entirely secondary to the identification of similarities and differences in the archaeological record. Upper Paleolithic taxonomic units, if employed, should be treated as heuristic, revisable concepts, useful largely for summarizing variability rather than as analytic units (Reynolds, accepted manuscript). In other parts of the archaeological record traditional taxonomic units have also been the subject of critical attention and their usefulness for describing variability or as analytical units is in many cases questionable (e.g. Scerri et al. 2014; Shea 2014; Groucutt, this volume). I consider that the description of variability is best done from the bottom up, with an explicit focus on specific features of material culture and other aspects of the archaeological record, and that it is not in fact necessary to attempt to place assemblages into discrete taxonomic units. For example, when evaluating the chronocultural framework of Gravettian sites, I consider it far more important to consider the 
differing distributions of the numerous Gravettian lithic index fossils (Gravette points, éléments bitronqués, shouldered points, Font-Robert points, Raysse burins, etc.), female figures and other features than to try and place sites into discrete taxonomic units or groupings.

An up-to-date synthesis of the chronocultural framework for the whole of the European Upper Paleolithic remains, at present, far from reach. Many good partial summaries of the archaeological record of particular regions or time periods are available but on the whole we have yet to find a way of integrating all the available information together in a way that formally clarifies our uncertainties and is useful as an interpretive model. To continue with our textile analogy, we would like a complete, smoothly woven canvas to work with, but although we have some good, strong threads in the right place, in both the warp and weft, there are also numerous fibers that need to be tied together, not to mention large holes to be filled and various mistakes to be undone and rewoven. Nevertheless, real incremental progress is being made in our understanding of the chronocultural framework of Upper Paleolithic Europe. In the following sections I describe the approach that is allowing this progress to be made. The approach I outline is not universally endorsed, and later in the chapter I will discuss some of its detractors' arguments.

There are two principal aspects to the construction and ongoing revision of the chronocultural framework for Upper Paleolithic Europe: material culture comparison and chronology. Both are necessary, and both have their strengths and weaknesses. In the next pages I discuss how we can use each of them to describe and revise our chronocultural framework. 


\section{Threading the weft: comparative material culture study}

Upper Paleolithic material culture from approximately contemporary sites across Europe often shows profound similarities. For example, there are apparent strong similarities between Aurignacian bladelets found across Europe (Le Brun-Ricalens et al. 2009; Tsanova et al. 2012; Dinnis et al. 2019), early Gravettian microgravette assemblages in Italy, Russia and elsewhere (Sinitsyn 2007, 2013; Moreau 2010; Wierer 2013; Reynolds 2014), and between female figures ("Venus figurines") found across Europe in late Gravettian assemblages (Mussi 2000; Soffer et al. 2000; Paris et al. 2017; Khlopachev et al. 2018). The strength of these similarities varies from case to case, and during some time periods there appears to have been more regionalisation in material culture than during others. Most archaeologists recognize the reality of these similarities, and furthermore assume that the similarities in material culture dating to the same time are because there were similarities between what people were doing at more than one location at the same time and that this is due to sociocultural connections between them, either direct or historical. In theoretical terms, this is based on ideas, in all their great variety, of the critical importance of social and cultural factors in shaping material culture and technological practice (e.g. Leroi-Gourhan 1964-65; Sackett 1982; Pigeot 1990; Dobres 1999; Pelegrin 2007; Mesoudi and O'Brien 2009; Knappett 2011; Jordan 2015; O'Brien and Bentley, this volume).

There are numerous aspects of material culture that can be examined from a comparative perspective. Lithic assemblages are the main basis for describing assemblage variation, but other aspects of material culture (e.g. personal ornaments, osseous assemblages) and, indeed, evidence beyond the strict definition of "material culture", such as the remains of dwelling structures, faunal assemblages and site distribution with respect to landscape, can also be used to tell us something about past similarities and differences (e.g. Iakovleva 2003; 
Vanhaeren and d'Errico 2006; Svoboda 2007; Goutas 2013; Perlès 2013; GaudzinskiWindheuser and Jöris 2015; Wojtal et al. 2018).

However, lithic techno-typology remains a key aspect of material culture comparison for the European Upper Paleolithic. Typology - when done well - is a powerful archaeological tool that is highly relevant to contemporary archaeological practice. Modern lithic artefact typology usually takes into account technological information, and the term "technotypology", from the French "techno-typologie" is increasingly encountered in Englishlanguage literature, emphasizing that lithic technology needs to be studied in combination with lithic typology: from the point of view of cultural taxonomy in particular, the two are inseparable. Modern day techno-typology studies the morphology and technology of lithic artefacts with a view to understanding the "types", either emic or etic, and the technological practices underlying artefact variation. Much modern work of this kind is highly revisionist, and applies a critical approach to previously established artefact types (e.g. Soriano 1998; Hays and Lucas 2000; Pesesse and Michel 2006; Le Brun-Ricalens et al. 2009; Klaric et al. 2009, 2015; Pesesse 2009-2010; Lev et al. 2011).

Techno-typology is vital to the definition and usage of index fossils (fossiles directeurs): chronologically and geographically restricted artefact types that are key to the comparison of assemblages. (The term "type fossils", often encountered in English-language archaeological literature, is a somewhat misleading usage, since in biology this term refers to the "type specimen" or "holotype" used as a reference for the formal definition of a species or population.) In Upper Paleolithic archaeology, lithic index fossils continue to be key to the definition and correlation of archaeological deposits. Because they have been a major focus of work over the years, and because they have been heavily used for inter-site comparison, our existing chronocultural framework and taxonomic units have largely been built using them. 
The relationship between a defined, ideal "type" and an actual physical group of archaeological artefacts can never be perfect. Questions of how to manage variability within groups of artefacts, how best to define formal types, whether to split or lump, and so on, are part of archaeological techno-typological practice and debate: the fact that in many cases there are no "right" answers to many of these questions does not mean that the whole enterprise is worthless (neither does it mean that our understandings cannot be improved). It is perfectly possible to carry out a pragmatic typology of artefacts by treating all of our types as heuristic, etic categories that are nonetheless potentially reflective of past sociocultural relationships (Hayden 1984; Dunnell 1986; Adams and Adams 2009: 282-284) (although it is important to recognize the limitations of this approach; e.g. Odell 1981). What this means is that we can use archaeologically recognizable, defined types for comparative purposes, regardless of our level of confidence that they were purposefully created by past people or that they were used, for example, to self-consciously demonstrate group affiliation (Wobst 1977; Sackett 1982, 1985; Wiessner 1983, 1985). Unconscious technological habits are just as important as conscious efforts in creating the traits and patterns that we see in past material culture, and are also subject to the forces of cultural inheritance, transmission and drift (e.g. Barton 1997; Hurt and Rakita 2001; Lyman and O'Brien 2004; Collard et al. 2009).

It needs to be noted that Upper Paleolithic index fossils are best established with a view not only to any inherent techno-typological distinctiveness but also to their distribution in the record. By this I mean, as has long been established, that useful index fossils are clearly restricted chronologically and often also geographically in the record (de Sonneville Bordes 1966; Demars and Laurent 1992). Endscrapers, burins sensu lato and other very common tool types are not suitable index fossils for defining the chronocultural framework of the European Upper Paleolithic. A good index fossil is one that can be clearly and explicitly defined using 
technological and morphological criteria, and that is clearly restricted within the archaeological record.

The question of the technological relationships between index fossils, and particularly whether separate index fossils reflect stages in the reduction of a single tool type, is also important. It is clear that the majority of Upper Paleolithic index fossils cannot feasibly have been converted from one type into another, in contrast to e.g. Middle Paleolithic scraper "types" (Dibble 1995). The risk of misidentifying index fossils as incomplete or modified versions of other index fossils, e.g. fragments of incompletely backed bladelets as shouldered points (Reynolds 2014, Polanská and Hromadová 2015, Wilczyński 2015), is widely understood among lithic specialists. Some of the variation that we do see within particular groups of artefacts may well be a reflection of the application of additional retouch to modify given tool types for use, as argued by Neeley and Barton (1994) for some Levantine Epipaleolithic tools. However, this is not a problem unless it causes the inappropriate definition of multiple index fossils (rather than the description of some artefacts as "atypical" examples): in any case, if one index fossil turns out to be simply an ad hoc modification of another tool type, then their geographical and chronological distributions should coincide.

We have come a long way since the formative studies of Upper Paleolithic lithic typology by de Sonneville Bordes and Perrot (1954, 1955, 1956a, 1956b), and even since the useful updates to this work by Demars (1990) and Demars and Laurent (1992). Recent work has focused closely on individual artefact types, their formal definition, the technology of their creation (often informed by a chaîne opératoire approach; see also Maher and Macdonald, this volume), and consideration of variability within the groups of artefacts attributed to each type. This has led to the definition of new types (e.g. éléments bitronqués/Late Gravettian rectangles in Central Europe; Polanská and Hromadová 2015; Wilczyński et al. 2015), the correction of previous misclassifications of artefacts (e.g. Kostënki knives in Western and 
Central Europe; Lev et al. 2011; Klaric et al. 2015); critical analysis of the coherence of particular types (e.g. northern European Final Paleolithic tanged points: Serwatka and Riede 2016), and systematic formal comparison and reclassification of traditional types (e.g. Early Upper Paleolithic bladelets from across Europe: Le Brun-Ricalens et al. 2009). This work is being carried out all over Europe and is making real, if necessarily piecemeal, improvements to our understanding of material culture variability.

The study of lithic technology sensu stricto - the full process of production of stone tools, from the first blows to a nodule to the final stages of retouch or resharpening of an artefact can also be used to compare assemblages. There are abundant possibilities for this type of comparison: for example, blank production strategies (e.g. specific features of blade and bladelet production in Proto-Aurignacian assemblages: Le Brun-Ricalens et al. 2009; Teyssandier et al. 2010; Bordes et al. 2011), retouch characteristics (e.g. lateralization of backing in Gravettian assemblages; Harrold 1993; Reynolds 2014), and the use of different types of percussion (e.g. varying usage of soft stone and organic hammers throughout the Upper Paleolithic in Western Europe; Pelegrin 2012).

Studies of lithic artefacts are informative at various scales. The production of backed bladelets and general pervasiveness of the use of abrupt backing for many thousands of years all over Europe, as seen in Gravettian and later assemblages, tells us something about the persistence of particular traditions on a large time-scale. On the other hand, the chronological and geographical restrictedness of certain distinctive index fossils and technological habits (e.g. bladelet production using various types of carinated artefacts; Bordes 2006) provides insights of a different kind.

Other types of material culture can also be used to explore the differences and similarities between sites, and, fascinatingly, often give a different picture of variation than lithic 
assemblages do. Osseous artefacts are in some cases already recognised as at least as important to inter-site comparisons as lithic artefacts, as is the case for Aurignacian osseous points and Gorodtsovian bone "paddles" (Sinitsyn 2010; Doyon 2019). Upper Paleolithic personal ornaments show complex patterns of variation that do not always map straightforwardly onto patterns seen in other aspects of material culture (Vanhaeren and d'Errico 2006; Perlès 2013; Rigaud et al. 2014). Female figures ("Venus figurines") have been found in late Gravettian assemblages across Europe dating to approximately the same time, but the lithic assemblages with which they are associated show clear typological differences (Efimenko 1958; Otte 1981; Gvozdover 1998; Lev 2009; Simonet 2012; Paris et al. 2017).

Comparisons between different aspects of material culture - including different aspects of lithic assemblages as well as of non-lithic assemblages - sometimes mirror each other and sometimes contradict each other. This should not be seen as a problem. These variances can tell us something about the complexity of social and population processes during the Upper Paleolithic (Vanhaeren and d'Errico 2006; Hromadova 2012; Perlès 2013; Goutas 2016). As shall be further discussed below, the key to managing and understanding this complexity within our chronocultural framework is to consider each aspect of material culture separately and to treat them all as potentially informative of past sociocultural processes.

The approach advocated in this chapter focuses on the presence/absence of particular features in assemblages. The high degree of variability of the Upper Paleolithic record makes it wellsuited to this type of approach. Although it does not provide a full picture of the similarities and differences between sites it is an excellent way to build a comprehensive preliminary bottom-up framework that does not rely on traditional top-down cultural taxonomy. It should be noted however that statistical comparisons of the technological or morphological attributes of assemblages have also proved useful for evaluating material culture variability and testing 
traditional taxonomic units (e.g. Scerri et al. 2014; Serwatka and Riede 2016; Doyon 2019). Here, given that the area of interest is the European Upper Paleolithic record as a whole, I have deliberately chosen an approach that facilitates the rapid comparison of a large number of assemblages and provides a very clear basis for comparisons. The incorporation of data on e.g. relative abundances of artefact types, or the results of multivariate statistical analyses, could in principle be combined with presence/absence data as part of the same framework, but this would require careful planning and would add greatly to the complexity of the functional, raw material and other factors that need to be considered in order to enable valid comparisons. A bottom-up chronocultural framework based on the presence/absence of particular features already provides many advantages over the traditional cultural taxonomic framework and, importantly, can feasibly be constructed for the entire European Upper Paleolithic record.

\section{Testing the warp: the importance of chronology}

The second main axis of our chronocultural framework is chronology, unquestionably key to the study of the Upper Paleolithic. Examining change through time on the site, regional or continental level requires understanding of both relative and absolute chronologies of assemblages. However, chronology is not a value-neutral field. Different archaeologists and archaeological scientists place varying emphasis on each aspect of chronology building, and these differences in emphases help to explain many of the most heated debates in Upper Paleolithic archaeology in recent years. Researchers have different ideas of what is best practice and differ in how the relationship between chronology and material culture comparisons should be managed. Here, I discuss stratigraphy and absolute dating in turn. 


\section{Stratigraphy}

Stratigraphy has been a key aspect of archaeological chronology building since the earliest days of the discipline and remains so. Its most basic principle - that archaeological material was physically deposited in chronological order - is simple and inarguable. In practice, of course, there are many nuances that need to be taken into account and that become increasingly important as we build chronologies in greater detail.

There are numerous recurrent problems in the study of stratigraphy. The lack of reliable and detailed stratigraphic information for many key excavations, especially early excavations, causes frequent difficulties (e.g. Gravina et al. 2018; Teyssandier and Zilhão 2018). Even where stratigraphic recording is impeccable, the complexity of formation processes can pose serious problems for interpretation. Stratigraphic units are also often treated as individually uniform despite the fact that we know that they do not necessarily relate to discrete collections of archaeological material and the divisions between them are often subject to error (e.g. Discamps et al. 2015). This issue comes into sharpest focus when we consider the problem of "mixing" between stratigraphic units. Refitting studies at numerous sites (e.g. Hahn 1988; Morin et al., 2005; Discamps et al. 2015; Gravina et al. 2018) have shown that contemporary material may be found in separate stratigraphic units, either due to taphonomic processes or to misinterpretations of stratigraphy during excavation. Problems with stratigraphy underlie many of the most intractable problems that we have in understanding the relationships between certain Upper Paleolithic assemblages.

\section{Radiocarbon chronology}

For the Upper Paleolithic, the most important method of absolute dating remains radiocarbon dating, although luminescence dating is of increasing importance, especially as precision and 
reliability improves (e.g. Lomax et al., 2014; Frouin et al. 2017). Radiocarbon dating is key to chronological comparison of assemblages, particularly from single-layer sites, but also for refining the chronology of long sequences.

Unfortunately, radiocarbon dating remains far from infallible. The fact that only tiny amounts of contamination containing modern carbon can skew results for Upper Paleolithic samples by thousands of years has rendered many published dates highly misleading (Higham 2011). Certain labs appear to be more reliable than others in producing accurate dates. There is considerable variation in methods used, and presumably in adherence to protocols during sample pretreatment and measurement. Methods have also changed over the years, with some clear improvements in reliability, at least at certain labs.

Methods for the AMS measurement of isotopes have already reached an extremely high level of accuracy (Bronk Ramsey et al. 2004). The part of the radiocarbon dating process that is more potentially problematic in the present day is the pretreatment of samples ahead of AMS measurement. Pretreatment generally involves the attempted isolation of a particular part of a sample. For charcoal, available pretreatment methods appear to be largely reliable for producing accurate results (Brock and Higham 2009, Haesaerts et al. 2013). However, the isolation of collagen from bone samples for dating is more methodologically challenging than sometimes understood: standard methods such as ABA (acid-base-acid washes), with or without ultrafiltration, cannot be said to reliably remove all non-collagen material from a sample, and the removal of conservation materials, even with the use of additional solvent washes, appears particularly problematic (Brock et al. 2013, 2018; Marom et al. 2013).

One of the most interesting and promising recent developments in radiocarbon dating has been the application of single amino acid (hydroxyproline) dating to bone samples. This method very effectively ensures the isolation of collagen material only, by using high- 
performance liquid chromatography (HPLC) to isolate the amino acid hydroxyproline, found almost uniquely in collagen. The isolation of hydroxyproline means that almost all contaminants (apart from collagen-based glues and preservatives) can be excluded, in principle leading to far more accurate dates than before. The method is expensive and laborintensive, and continues to be subject to methodological improvements (McCullagh et al. 2010; Marom et al. 2013; Nalawade-Chavan et al. 2014; Devièse et al. 2018). Nevertheless, it has produced some outstandingly interesting results, including the first convincing, consistent dates for the burials from Sungir', Russia (Marom et al. 2012), which have been difficult to date due to the heavy contamination of the human remains and other archaeological material with preservatives.

Recent results obtained using this method, however, should also focus attention on the potential shortcomings of more established radiocarbon dating methods. Although the problems with contaminated material are well known, new results of single amino acid dating suggest that even material with a pristine curatorial history may be difficult to date accurately. In one study, two bone samples from recent excavations at Abri Blanchard, France were dated using both the established ABA/ultrafiltration method and the single amino acid method: the latter produced results that were several thousand years older (Bourrillon et al. 2018). The authors of the study suggested that the site's geochemistry may have something to do with the discrepancy in dating, as humic acids deriving from groundwater may have become cross-linked with collagen molecules, causing the results obtained from conventional methods to be incorrect. In a further example, bones and personal ornaments from Kostënki 17/II, Russia, dated using both ABA/ultrafiltration methods and the single amino acid dating method produced dates where, again, the results from the latter method were several thousand years older than those from the former (Dinnis et al. 2019). Although the dated bones were from twentieth-century excavations and their curatorial 
history is incompletely known, they were not visibly treated and they were washed with solvents at the beginning of sample pretreatment, in an attempt to remove any invisible glues or preservatives (Brock et al., 2010).

In both these studies the bone samples were very similar to many others that have been assumed to be entirely suitable for standard ABA/ultrafiltration dating. The only reason that we know that in these cases the dates produced using $\mathrm{ABA} / \mathrm{ultrafiltration}$ are inaccurate is because we also have results obtained using the hydroxyproline method. These archaeological examples echo the results of experiments where a ${ }^{14} \mathrm{C}$-depleted bone, ca. 60 70 thousand years old, was soaked in hot tea for one hour to mimic the effects of humic and fulvic acids on buried archaeological samples (Marom et al. 2013). Despite applying pretreatment methods including ultrafiltration, the radiocarbon date subsequently produced from the treated sample was ca. $22 \mathrm{kya}{ }^{14} \mathrm{C} \mathrm{BP}$, showing that ca. $6 \%$ of the dated carbon derived from the modern tea. Single amino acid methods, however, successfully produced an infinite radiocarbon date for the treated sample indistinguishable from that obtained from control samples.

Unfortunately, we have no routine way at present of determining whether an archaeological sample has been affected by, for example, contact with humic and fulvic acids in soil and groundwater. This is a significant blow to efforts to create detailed chronologies based on radiocarbon dates from bone samples: it means that any date not produced using the single amino acid technique, especially for the earlier part of the Upper Paleolithic where contamination causes more acute problems, must be treated as questionable until these processes are better understood. Furthermore, where dates are wrong, they will likely appear to be younger than they should: this means that this factor does not introduce random statistical noise, but in fact causes bias in one direction. Therefore, Bayesian statistical methods as currently employed in radiocarbon chronology building are not appropriate to 
counteract this source of error. The effects of geochemistry on radiocarbon dating samples must be treated as a priority area for research; so too must the development of statistical modelling methods for compensating bias in radiocarbon dates using stratigraphic and archaeological information.

The known problems with stratigraphy and radiocarbon dating are a principal reason for my support of a dialectical approach to the construction of the Upper Paleolithic chronocultural framework. To obtain a strong chronological framework, it is not enough to uncritically accept the results of absolute dating of particular artefacts or stratigraphic units: we need to use material culture comparisons to inform our chronological inferences. In the next section, I outline how this works in practice.

\section{Coherence and convergence}

The preceding sections described both principal axes of the Upper Paleolithic chronocultural framework: material culture comparison and chronology. Because neither chronology nor material culture comparison are infallible and neither alone can describe the chronocultural framework, we need to combine them dialectically, carefully weighing evidence from both sides. In order to do this, we need a theoretical position. The position advocated here is to assume coherence in the archaeological record: i.e. to assume that similarities in archaeological material cluster geographically and temporally. This is based on the assumption that similarities that we see in the archaeological record are the result of similarities in behavior between people in the past, and that people who were closer in time and space tended to be more similar in behavior. This approach sees variation in material culture as having been shaped by historically situated activity within a social context: in other words, that many of the similarities and differences we see are the result of relationships between people, either through contemporary interaction or through relationships of 
inheritance from a common ancestor (e.g. Sackett 1982; Dobres 1999; Mesoudi and O'Brien 2009; Knappett 2011; Tixier 2012; Jordan 2015; O'Brien and Bentley, this volume). Furthermore, it assumes that the mobile hunter-gatherers of the Upper Paleolithic were highly socially connected across long distances, and that cultural changes spread quickly by diffusion. Therefore, we should not expect to see the static, geographically restricted existence of particular traditions over many thousands of years in a small area.

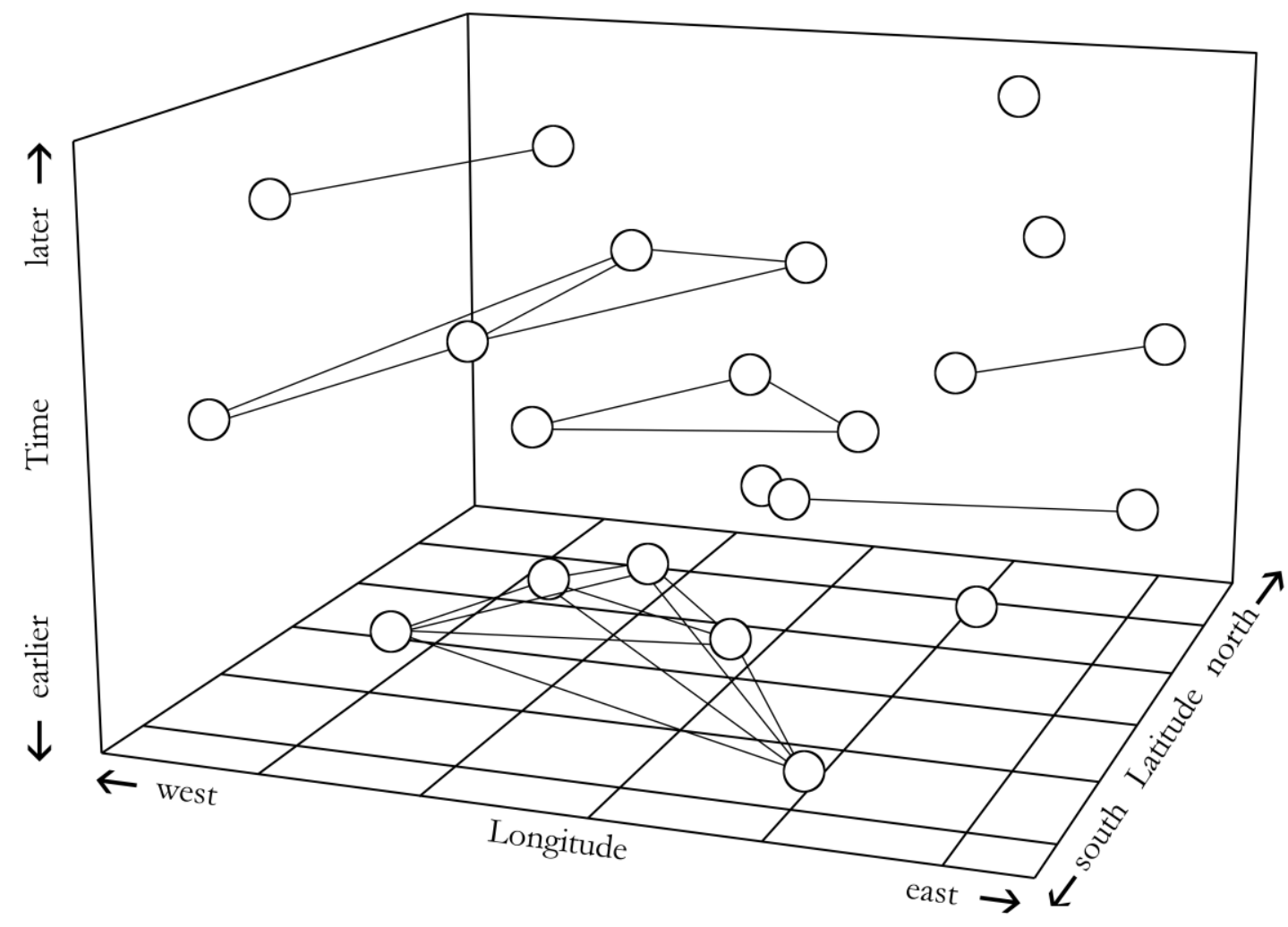

Fig. 2: Threading the weft: a simplified schematic diagram representing one way that we can visualize the Upper Paleolithic archaeological record. Spheres represent assemblages, and are placed in a chronospatial framework according to their estimated age and geographical location. The spheres are connected by lines where assemblages share a temporally restricted, well-defined material culture feature (e.g. an index fossil, a particular technology). This way of conceptualizing the archaeological record is the basis of the approach advocated in this chapter. 


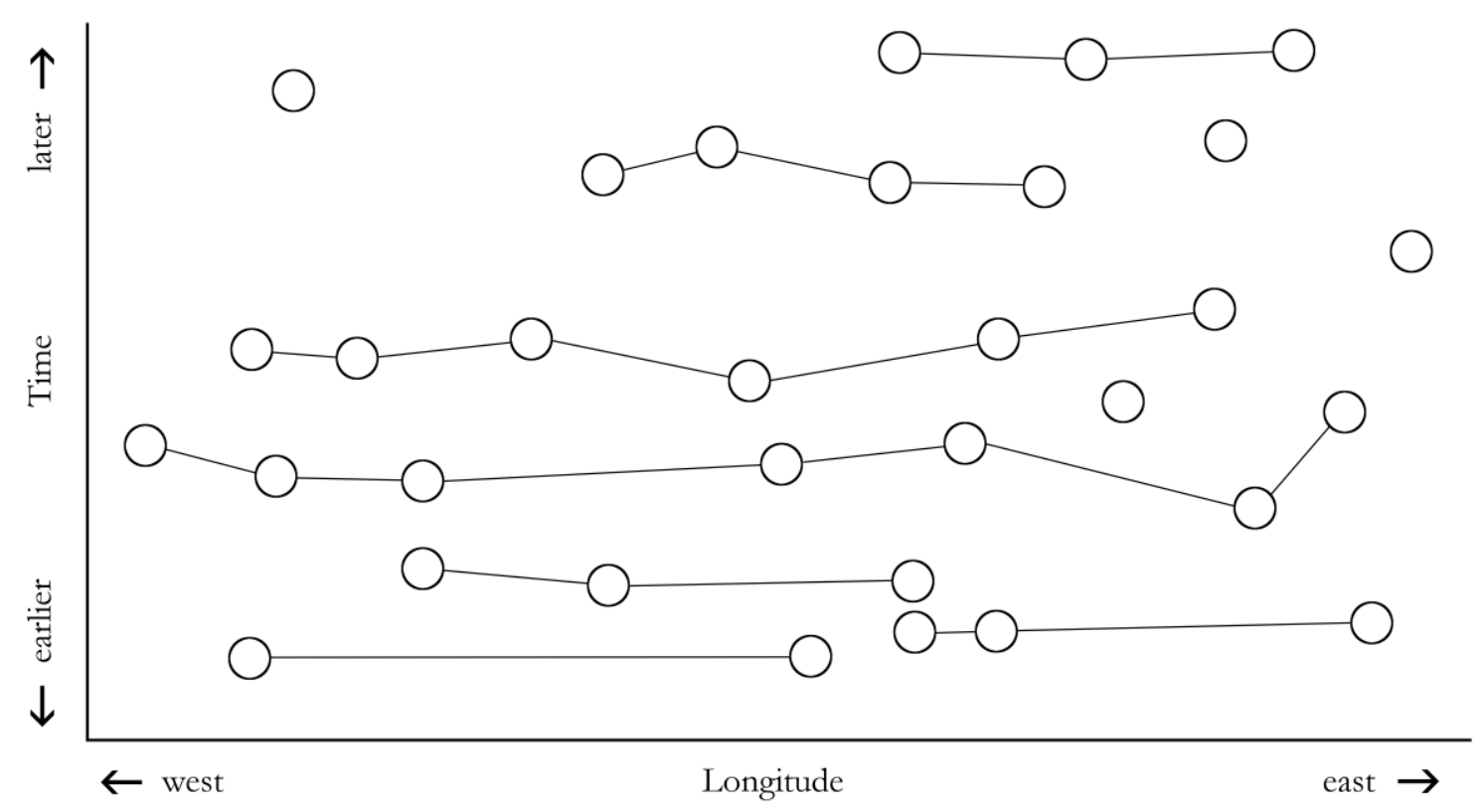

Fig. 3: An example of a simplified 2-dimensional depiction of the relationships between sites, similar to that in Fig. 2 but omitting the third axis (Latitude). This type of figure will be used in the rest of this chapter for the sake of simplicity.

In practice, and based on the examples where we have good understandings of both chronology and material variation, what does the archaeological record of Upper Paleolithic Europe look like? Ideally it needs to be envisaged as a three-dimensional model, with time in the vertical dimension and space in the two horizontal dimensions (Fig. 2), although for the sake of illustration we can also envisage it as a two-dimensional model, with time in the vertical dimension and space in the single horizontal dimension (Fig. 3). But in any case, when we focus on the most chronologically and geographically restricted index fossils and other features, we can use them to link series of assemblages across space. This leads back to the "warp and weft" analogy used in this chapter: we can link assemblages according to their temporally most specific aspects, in which case they cluster closely in the vertical, time 
dimension, and are dispersed to a greater or lesser extent in the horizontal, space dimension, just like colored threads on a loom. However, we can also use less temporally specific aspects

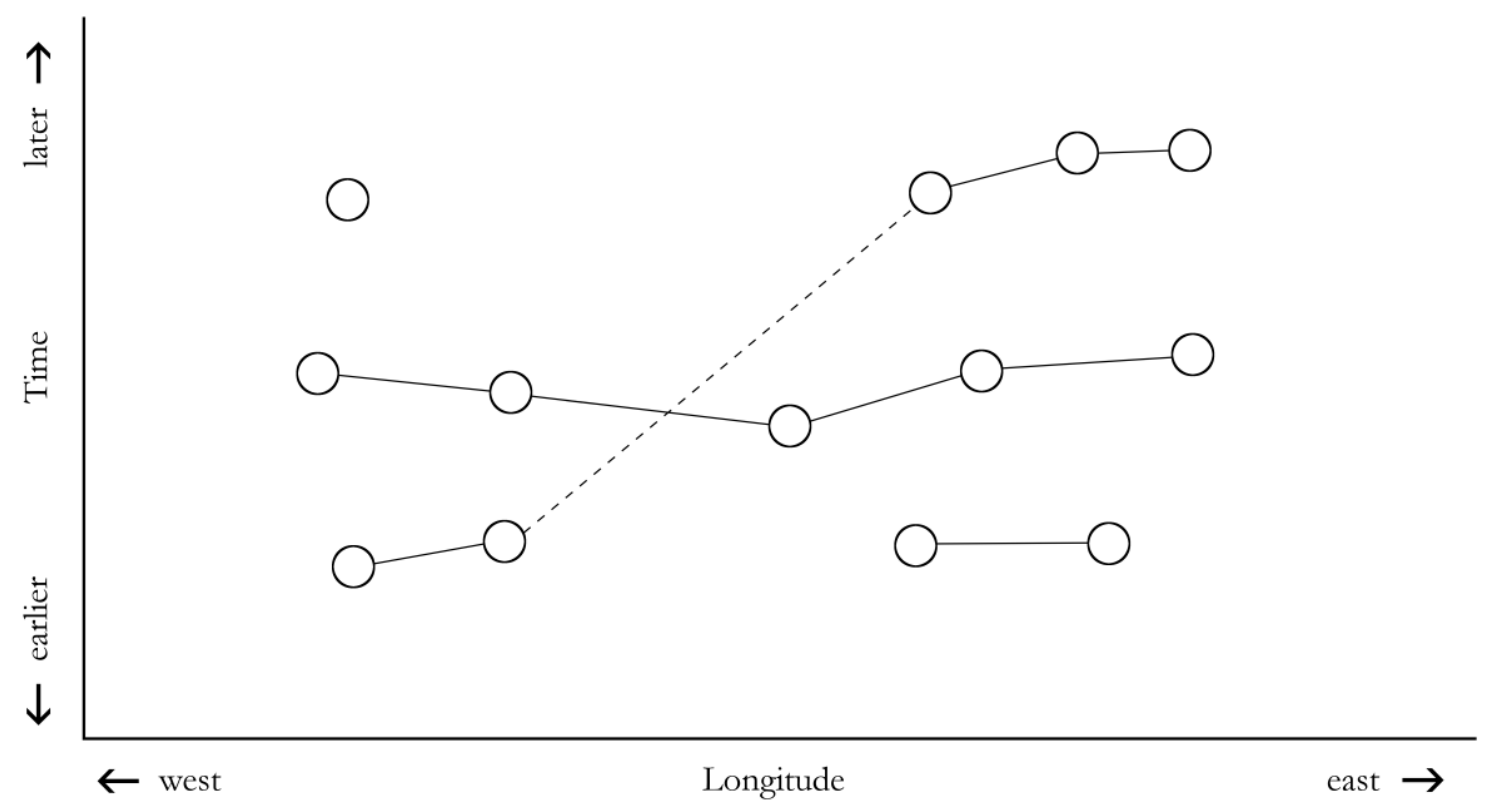

Fig. 4: Testing the warp: the identification of problems with the data or of convergence. Here, the dashed lines join assemblages that are distant in time but apparently share a material culture feature. Where this kind of result is obtained, both the accuracy of the material culture comparison and of the chronology of the assemblages should be questioned. If both are judged to be robust, and if there are no chronologically intermediate assemblages with similar material culture, and if there is a significant period of time between the younger and older assemblages (perhaps more than several thousand years) then the similarities between the assemblages are best treated as an example of convergence and no cultural link inferred or described between them. 
of assemblages (e.g. backed lithic technology in Gravettian and later assemblages) to link large groups of sites over long periods of time. Artefact types with very little geographical or temporal specificity, including non-specific burins, endscrapers, retouched blades, etc. are not useful for this exercise.

The assumption of coherence creates certain expectations, with consequences for how we evaluate archaeological information. For example, if a particular well-defined index fossil is found at eight sites within a region, and six of these sites are radiocarbon dated to within two thousand years of each other, but two sites are dated to six and ten thousand years younger than the other sites, then at the final two sites both the identification of the index fossil and the dating of the assemblage should be questioned (Fig. 4). This extends to the occasional claims for extremely precocious appearances of certain types of assemblage, further discussed below. In another example, if the same well-defined and rare technological feature appears in a number of sites in two different regions, dated to approximately the same time, it is fair to ask whether there was some kind of connection between them even if there appears to be a geographical discontinuity in their distribution. In both cases, there are ways of further investigating the situation: in the first, by re-examining the lithics and re-dating the assemblages, in the second, by searching in collections from geographically intermediate sites to see if the same technological feature can be identified. Conversely, where similar archaeological features are found in assemblages that are securely dated to different periods and are perhaps geographically distant, without any evidence for the same features in intermediate part of the record, then we may have identified a case of convergence.

The question of convergence in Upper Paleolithic industries is more easily addressed than sometimes claimed (e.g. Clark and Riel-Salvatore 2006). Examples of convergence in artefact form and technological features can be identified within the Upper Paleolithic archaeological record. For example, Anosovka points, found in late Gravettian assemblages in Russia and 
Ukraine are similar to backed points found in Late Upper Paleolithic assemblages in northern and western Europe, including Federmesser points (Schwabedissen 1954; Baales et al. 2001; Beliaeva 2002; Sinitsyn 2007, 2014; Sobkowiak-Tabaka 2017; Reynolds et al. 2019). The assumption of coherence in the archaeological record greatly facilitates the evaluation of convergence. In order to assess possible convergence, we identify the assemblages where a particular feature is present, and consider whether they are geographically and chronologically contiguous. Gravettian sites with Anosovka points and Late Upper Paleolithic sites with Federmesser and other backed points each form a geographically and chronologically coherent group, but these two groups are independent both geographically and chronologically. We can assume that the finds of Anosovka points at several sites in eastern Ukraine and western Russia at the end of the Mid Upper Paleolithic were not the result of convergence. However, their similarities with much later, and geographically distant, Late Upper Paleolithic backed points are the result of convergence. The separation of geographically and chronologically distinct groups of assemblages allows us, if necessary, to use similar or even identical material culture criteria for defining more than one group of assemblages.

It gets more difficult to identify true cases of convergence as features become more frequent in the archaeological record (see also Will and Mackay, this volume): is the common, but not universal, appearance of simple truncated backed bladelets in Gravettian assemblages the result of convergence, or can we use it to establish links between assemblages? There are several possible responses to this problem. First, we can simply avoid using a particular feature as the basis of establishing material culture similarity where such doubts are present. Second, we can examine carefully the exact distribution of the artefact type in the record, to see whether there is more patterning to its distribution than we previously thought. Finally, we can try to refine the criteria used, in order to see if distinctions can be made. For example, 
truncated backed bladelets sensu lato may not be useful for establishing connections between assemblages, but the specific type of truncated backed bladelet known as éléments bitronqués/Late Gravettian rectangles probably are: they appear to form a geographically coherent, temporally restricted group in Central and Eastern Europe in assemblages dating to the late Mid Upper Paleolithic (Rogachëv and Anikovich 1982; Lisitsyn 1998; Reynolds 2014; Polanská and Hromadová 2015; Wilczyński et al. 2015; Lisitsyn 2015).

\section{Alternative perspectives}

Not all researchers subscribe to the approach set out above. The theoretical conflict between approaches that do and do not prioritize the "big picture" of chronocultural coherence have been the cause of some of the most acrimonious recent debates in Paleolithic archaeology. This especially relates to claims for precocious evidence of the appearance of particular types of assemblage in particular small regions, often several thousand years before they appear elsewhere in Europe. These claims are typically based on the dating of individual assemblages. If we adhere to the concepts of coherence outlined above, we will likely reject the possibility of such early, localized appearances.

Some prominent recent examples of this include claims for extremely early Aurignacian assemblages at Geissenklösterle and Willendorf II (Conard and Bolus 2003; Higham et al. 2012, 2013; Nigst et al. 2014), and extremely early Gravettian assemblages at Buran-Kaya III (Yanevich 2014). These ideas contravene the theoretical approach outlined above, and have been criticized on such grounds. For example, the recent criticism by Teyssandier and Zilhao (2018) of the extremely early dating of an Early Aurignacian assemblage at Willendorf II was in part initiated by the observation that the dating of an Early Aurignacian assemblage to several thousand years earlier than any other Early Aurignacian assemblage violated principles of coherence similar to those described above. ("Early Aurignacian" assemblages 
form a distinct sub-group of Aurignacian assemblages, characterized by a series of technological and typological features, and the term does not simply refer to Aurignacian assemblages with early dates). The authors confirmed the validity of their critique by examining, and finding significant flaws in, the stratigraphic association between the dated samples and the Early Aurignacian assemblage at Willendorf II. However, the critique was provoked by a theoretical observation. The claim for an extremely early Aurignacian assemblage at Geissenklösterle has similarly been criticized based on a detailed examination of the stratigraphy of the site, a critique which was again provoked by the observation that the claim violated a theoretical model of the appearance of Aurignacian assemblages across Europe (Zilhao and d'Errico 2003; Banks 2015). Likewise, the claim for an extremely early Gravettian assemblage at Buran-Kaya III has been rejected on the grounds of its chronological difference from all other Gravettian assemblages (Hublin 2015; Reynolds and Green 2019). Critiques of this kind have an important part to play in strengthening the chronocultural framework for Upper Paleolithic Europe as a whole, although they need to be backed up with empirical evidence to be truly convincing.

The sociocultural significance of material culture variation within the Upper Paleolithic record has also been challenged from various perspectives, often resulting in some degree of dissent from the approach set out above. For example, it has been argued that in the vast majority of cases it is not possible to reconstruct the intentions of the manufacturers and users of Paleolithic stone tools, and that this has a bearing on the typological study of assemblages (e.g. Marks et al. 2001; Dibble et al. 2016). However, such arguments do not undermine the approach advocated in this paper. First, in many cases the recognition of broad-scale patterning in Paleolithic material culture can be achieved regardless of whether we have fully analyzed the material and attempted to reconstruct the intentions of its creators: certain lithic index fossils and other features are very clearly restricted to certain parts of the 
archaeological record even if they are not yet satisfactorily understood from a technological and functional perspective. Second, I would argue (following many others, including Mellars 1989; Pelegrin 1991; Tixier 2012) that in many cases from the Upper Paleolithic we can reconstruct past intentions of creation to some degree. In assemblages where, for example, there are many hundreds of examples of a particular, technologically and morphologically homogeneous and meticulously created stone tool, dominating the retouched assemblage (e.g. microgravettes at Kostënki 8/II, Noailles burins at level IV of Isturitz; Sinitsyn 2007; Lacarrière et al. 2011; Reynolds 2014), it seems perfectly reasonable to assume that these artefact types were deliberately and systematically created. The idea of systematic creation may in fact be particularly important to the interpretation of material culture variation: a single artefact may be intrusive or an ad hoc creation; several hundred highly similar artefacts probably are not. A long debate played out during the late twentieth century concerning the difference between emic and etic typological categories (e.g. Hayden 1984; Dunnell 1986; Read 1989; Lyman and O'Brien 2004; Adams and Adams 2009; Van Oyen 2015); however, for the purposes of chronocultural framework building, it is perfectly acceptable to assume that all our typological categories are etic in nature. As long as our index fossils and other features are well-defined and restricted in the record, we can use them for chronocultural framework building, whether or not we think that the people who created and used them would have identified them as constituting a single category.

Some authors have also doubted the degree of cultural significance that should be attributed to Paleolithic lithic artefacts, seeing variability rather as largely the result of functional and mobility factors (e.g. Riel-Salvatore and Clark 2001; Clark and Riel-Salvatore 2006). The same authors also doubt that the resolution of the archaeological record is great enough to allow us to discern any cultural component that might exist in lithic variability. This sort of criticism perhaps fails to take into account the numerous examples where we do have 
excellent evidence for geographically and temporally restricted artefact variation. Although many assemblages are certainly palimpsests of multiple phases of occupation, this does not necessarily prevent us from defining variation in the record, much of which is best understood on a long-term scale in any case. For most archaeologists, at least some of this variation is best explained by cultural factors.

Finally, an obvious criticism to be levelled at the approach described here concerns the possibility of "leads" and "lags" in the distribution of particular material culture types: in other words, in identifying the spread of particular traditions. If we assume general contemporaneity between assemblages with similar material culture, and if we preferentially question radiocarbon dates and stratigraphic information that contradicts this assumption of contemporaneity, then it could be argued that we are excluding the possibility of identifying the earliest (or latest) occurrence of a particular type of material culture.

There are both theoretical and methodological responses to this. In theoretical terms, it must be remembered that we are dealing with the material traces of mobile hunter-gatherers, and so the particular geographical "origin" of a given material cultural trait may be extremely difficult to define (Teyssandier and Zilhão 2018): the earliest appearance of a given trait in the archaeological record may post-date the diffusion of the trait across hundreds or thousands of kilometers. Furthermore, in methodological terms, for most of the Upper Paleolithic our absolute chronological resolution is insufficient to identify small leads or lags in the appearance of particular features or of groups of features (d'Errico and Banks 2015; Reynolds and Green 2019). For most of the Upper Paleolithic we are working at a chronological resolution that does not allow us to reliably identify leads and lags of less than a thousand years, the scale at which most transitions likely took place. In this context, the assumption of near-contemporaneity between materially similar assemblages is acceptable, at 
least when building the first approximation of this framework. Further refinements, including the identification of possible leads and lags, become easier as the framework is established.

\section{A brief case study: Mid Upper Paleolithic Russia}

Perhaps the best way to clarify the approach outlined in this paper is to present a case study of how it works in practice. Here, I discuss the Mid Upper Paleolithic (MUP; ca. 30,000$22,000{ }^{14} \mathrm{C}$ BP or ca. $34,000-26,000$ cal BP) Gravettian record of European Russia. This is to show how a dialectic approach to radiocarbon chronology and assemblage comparison can be used to develop a working hypothesis of a chronocultural framework. Particular assemblages can then be targeted for further work, allowing us to strengthen and refine the framework.

There is only one Gravettian site in Russia dating to the early MUP: Kostënki 8/II, with a rich assemblage of microgravettes, dating to around $28-27,000{ }^{14} \mathrm{C}$ BP (Reynolds et al. 2015). There are no clear analogies in Eastern Europe for this site: comparisons have, however, been made with assemblages of approximately the same age containing microgravettes from sites across Europe such as Grotta Paglicci, Grotta della Cala, Geißenklösterle and Abri Pataud (Sinitsyn 2007, 2013; Moreau 2010; Wierer 2013; Reynolds 2014).

Two Gravettian sites in Russia have now been directly dated to ca. $25,000{ }^{14} \mathrm{C}$ BP: Kostënki 4 and Borshchëvo 5 (Reynolds et al. 2015). Although it is very difficult to find strong contemporary analogies for the site of Kostënki 4 (Reynolds 2014; Zheltova 2015), the Borshchëvo 5 assemblage does find clear similarities in that from Kostënki 9 (Sinitsyn 2007, 2015; Lisitsyn 2015), due to the shared presence of éléments bitronqués. Éléments bitronqués were, however, also found at the slightly younger site of Kostënki 1/I, included in the Kostënki-Avdeevo Culture and probably dating to ca. 24,000-23,600 ${ }^{14} \mathrm{C}$ BP (Lisitsyn 1998; Haesaerts et al. 2017). There are no radiocarbon dates yet available for Kostënki 9, but it seems reasonable to assume that Kostënki 9 dates to approximately the same time as 
Borshchëvo 5 and/or Kostënki 1/I based on their assemblage similarities. If radiocarbon dates can be obtained for Kostënki 9, this will help to test and refine this proposition.

A relatively large group of Gravettian sites is attributed to the Kostënki-Avdeevo Culture, including Kostënki 1/I, 13, 14/I and 18, Avdeevo, and Zaraisk, probably dating to ca. 24,00022,500 ${ }^{14} \mathrm{C}$ BP (Sinitsyn et al. 1997; Amirkhanov 2000; Abramova et al. 2001; Haesaerts et al. 2017; Reynolds et al. 2017). Shouldered points were found at all of these sites, and they have other lithic techno-typological features in common. Female figures were found at Kostënki 1/I, 13, Avdeevo and Zaraisk (Abramova 1995; Amirkhanov and Lev 2008). Long lines of hearths associated with pits were also found at Kostënki 1/I, Avdeevo and Zaraisk (Efimenko 1958; Bulochnikova 2008; Amirkhanov 2009).

The relationship of the site of Gagarino to this group has long been debated. Female figures and small shouldered points were found there but it lacks the large shouldered points found at the other sites, while its available radiocarbon dates are relatively young, and suggest that the site post-dates ca. 22,000 ${ }^{14} \mathrm{C}$ BP (Tarassov 1971; Tarasov 1979; Sinitsyn et al. 1997; White 1997; Bulochnikova 1998; Sinitsyn 2007; Reynolds et al. 2019). However, technotypological study of the lithic assemblage and of the shouldered points suggests that the absence of large shouldered points at the site may be due to raw material factors (Es'kova 2015; Reynolds et al. 2019). Gagarino may well be earlier in age than its radiocarbon dates suggest, and closer to the age of Kostënki 1/I, Avdeevo and Zaraisk. Again, further radiocarbon dating may help to test this proposition.

The site of Khotylëvo 2 presents more difficult challenges. This site is dated to ca. $23,000{ }^{14} \mathrm{C}$ BP (Gavrilov et al. 2015), and, like Gagarino, its relationship to the Kostënki-Avdeevo Culture sites has been the subject of debate. Female figures were found at the site (Abramova 1995; Gavrilov et al. 2015) but the artefacts previously identified as shouldered points are in 
fact better described as variants of Gravette points (Reynolds 2014). Here, we can use the female figures and some lithic types (Kostënki knives, backed bladelets) to link the site with

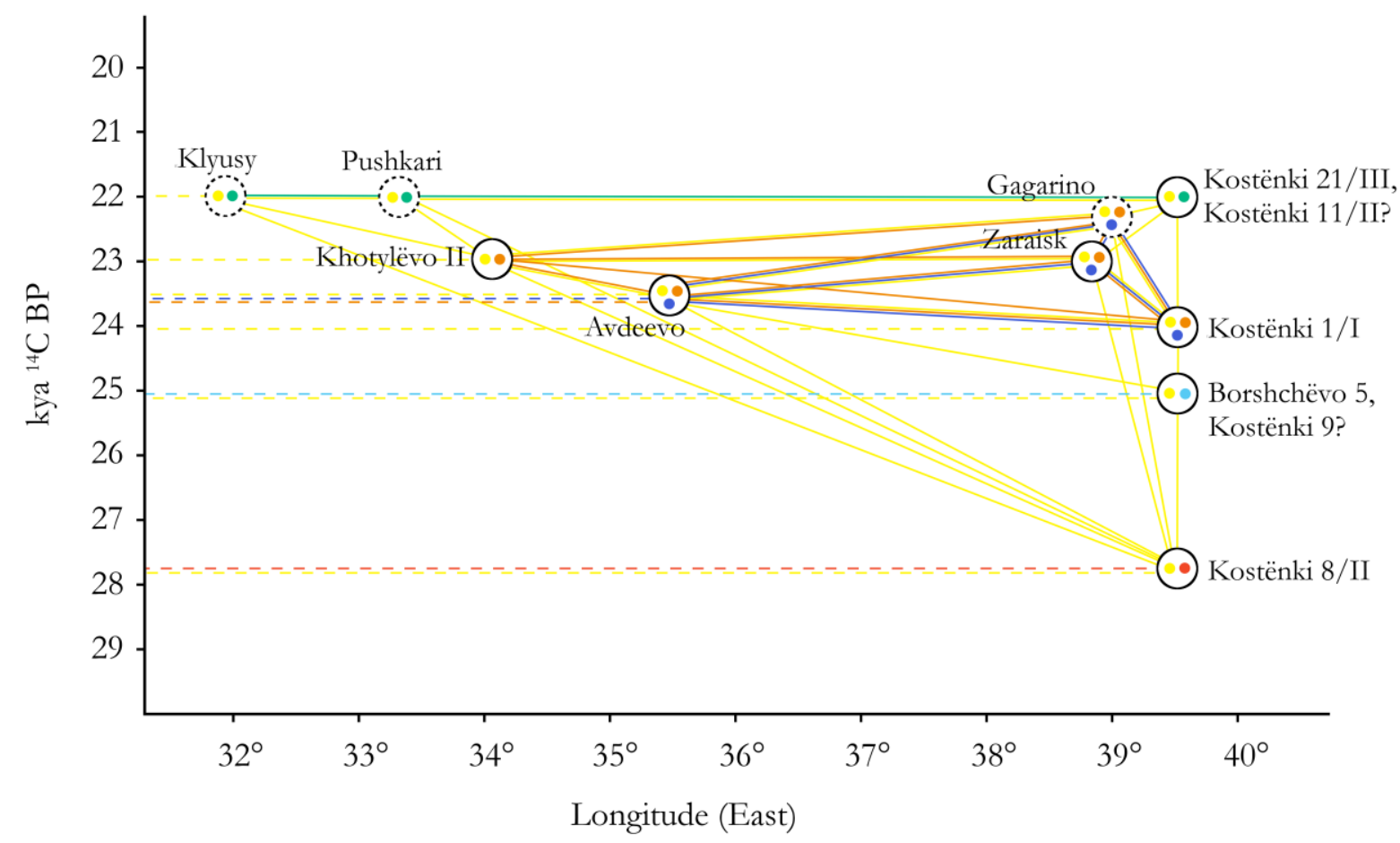

Fig. 5: A provisional chronocultural framework for Gravettian sites in Russia and eastern Ukraine. Key: Solid circles: well-dated sites. Dashed circles: sites whose dating is postulated based on material culture comparisons. Dots in circles: indicate presence of an index fossil or other feature used for comparison. Solid lines: indicate co-presence of index fossils or other features. Dashed lines: indicate co-presence at sites further west (exact chronological relationships not defined here). Colors of dots and lines indicate which material culture features are present: yellow - backed lithic technology; green - Anosovka points; orange female figures; dark blue - Kostënki-Avdeevo-type shouldered points; light blue - éléments bitronqués; red - systematic microgravette production. 
Kostënki $1 /$ I etc; the question of whether the site should be described as belonging to the Kostënki-Avdeevo Culture or not can be left aside under the approach followed here.

Finally, we can link a series of late Gravettian sites in Russia and Ukraine where Anosovka points have been identified: Kostënki 21/III (North), Kostënki 11/II, Pushkari I, and Klyusy (Praslov and Ivanova 1982; Rogachëv and Popov 1982; Ivanova 1985; Beliaeva 2002; Sinitsyn 2007, 2014, 2015; Gavrilov 2016; Reynolds et al. 2019). Although there is some uncertainty over the dating of these sites (e.g. there are no radiocarbon dates available for Klyusy), it seems safe to assume their approximate contemporaneity as a working hypothesis.

These examples allow us to build up a basic chronocultural framework for the Gravettian record in Russia based on the presence/absence of particular assemblage features (Fig. 5). Backed lithic technology is present at all sites mentioned. Systematic production of microgravettes is attested at the earliest site; full-sized Gravette points and éléments bitronqués appear later; shouldered points appear for the first time about a thousand years after that, usually in association with female figures although one site has female figures and no shouldered points; finally, Anosovka points appear. This is a highly simplified schema: to these index fossils we could add further lithic techno-typological features, specific aspects of personal ornament and osseous assemblages, and details of the remains of dwelling structures (e.g. Efimenko 1958; Hromadova 2012; Goutas 2013).

It should be emphasized that although I do acknowledge pre-existing taxonomic units (e.g. Kostënki-Avdeevo Culture), I do not attempt to construct further taxonomic units based on this record (which might be called Tel'manskian, Alexandrovskian, Borshchevskian, Anosovskian) because in my view it is not essential to understanding or analyzing variation in the record. What is perhaps more interesting is to consider the different geographical distributions of each of the discussed index fossils: from the distribution of microgravettes 
(and Gravette points) across Europe (Sinitsyn 2007, 2013; Moreau 2010; Wierer 2013), to the more restricted distributions of éléments bitronqués and shouldered points to Eastern and Central Europe (Grigor'ev 1993; Lisitsyn 2015; Polanská and Hromadova 2015; Wilczyński et al. 2015), to the much smaller distribution of Anosovka points in a small area of southwestern Russia and eastern Ukraine (Reynolds et al. 2019). Whether the distributions of these index fossils map onto past populations, or whether they do in all cases, remains impossible at present to answer, but they provide a far better dataset to address such questions than the traditional cultural taxonomic framework.

\section{Can we infer the existence of past populations from the archaeological record?}

In previous sections of this paper, I have briefly outlined how population concepts are commonly used in the modern study of the Upper Paleolithic, especially their frequent correlation with cultural taxonomic units (Aurignacian, Magdalenian, etc). I have also shown that the conceptualization of discrete populations associated with such taxonomic units (Aurignacians, Magdalenians, etc) has a long history, and outlined some of the many, widely acknowledged problems with the Upper Paleolithic cultural framework as it stands. We cannot assume that every taxonomic unit is equivalent in terms of its robusticity, its discreteness, or the amount of variation it subsumes. Without even going into some of the more sophisticated possible theoretical objections, this fact alone means that it is inappropriate to equate taxonomic units with past populations.

In an attempt to go beyond these problems, I then described an approach to the study of the Upper Paleolithic whereby the chronocultural framework of this period is established based on an assumption of geographical and temporal coherence in the material culture record. This kind of approach is widely used in the study of the European Upper Paleolithic, and holds out 
the possibility of significant further progress in developing and revising our chronocultural framework despite the known problems with chronology and the current incompleteness of our knowledge of material culture variation.

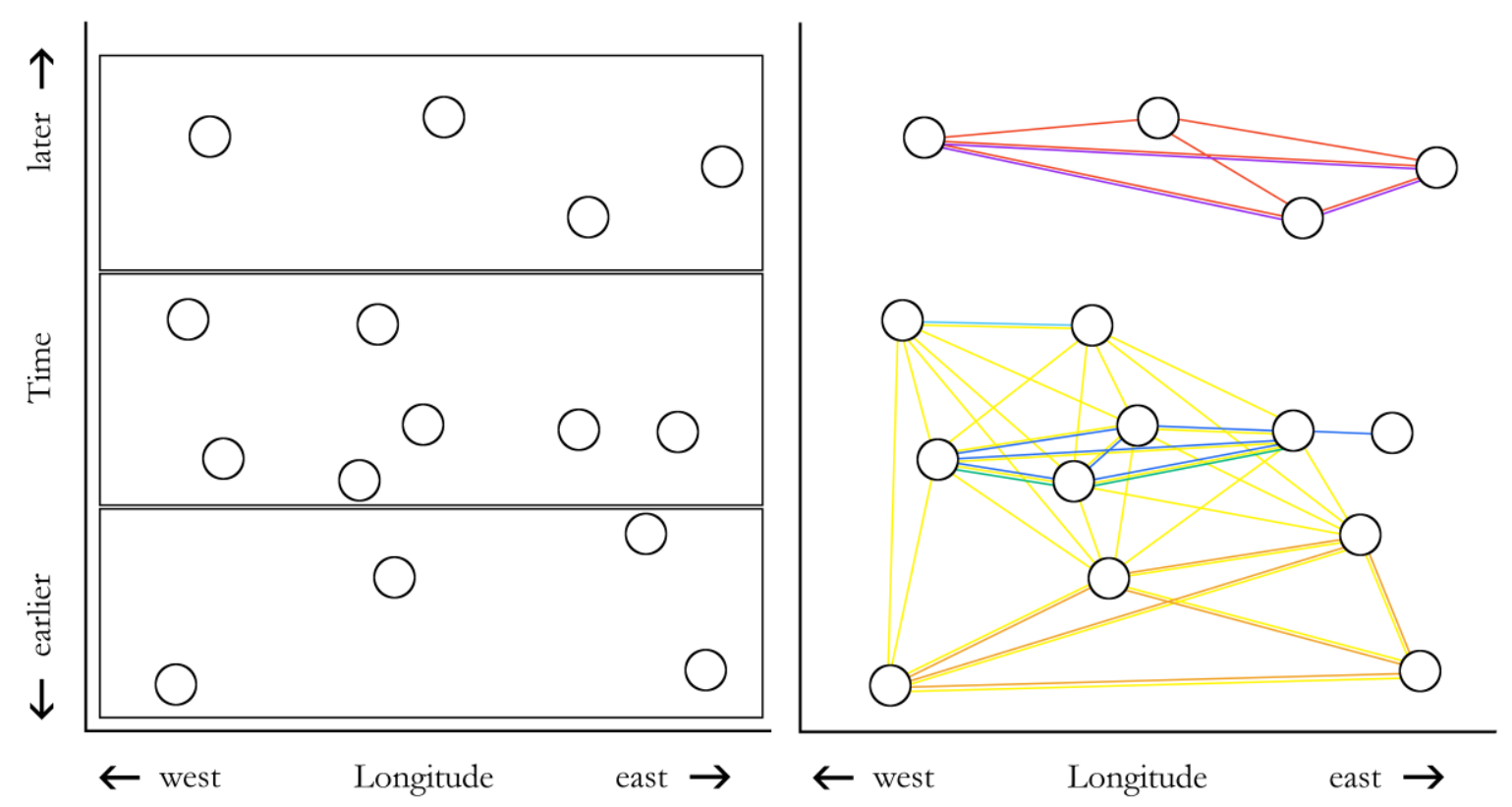

Fig. 6: One way of visualizing the differences between top-down (left) and bottom-up (right) approaches. Traditional approaches to cultural taxonomy (left) focus on placing assemblages into cultural taxonomic units, which often fail to reflect the complexity of the differences and similarities between sites. The approach advocated in this chapter (right) focuses on defining individual links between sites based on the co-presence of index fossils and other features.

The reason for going into so much detail regarding this approach is that I think it is necessary to fundamentally reconsider our entire cultural taxonomic framework if we are to successfully engage with questions concerning populations during the Upper Paleolithic. I also think that the approach outlined here is the best available method for doing so. One of the bases of this approach is the assumption that the relatively short-lived, often geographically restricted groupings of sites that we can establish based on the presence of 
particular carefully defined index fossils or other features do reflect past social connections between people. As a result, they have a direct bearing on questions of populations.

There is wide agreement within our discipline on the importance of synthesizing material culture and chronological data and of the identification of patterning and coherent groupings in the archaeological record. The distinctiveness of the approach put forward here, if any, lies in its insistence on a firmly bottom-up rather than top-down description of the archaeological record. Since the approach treats the definition of taxonomic units as an additional, optional step to working out the similarities and contrasts between sites, it does not require the definition of taxonomic units such that all sites can be placed into discrete taxonomic units (Fig. 6). Furthermore, it does not attempt to place units into a hierarchical system, unlike most of the current cultural taxonomic system as described above, Clarke's approach set out in Analytical Archaeology (1968), or some of the evolutionary archaeological approaches advocated by other researchers (e.g. Riede 2011). Instead, we can define connections between sites based on many different kinds of evidence, and at many different scales. Some of these connections will overlap and echo each other, while others will diverge. So, for example, we can describe a geographically and chronologically coherent group of sites dating to the Mid and Late Upper Paleolithic all over Europe showing evidence for the systematic production of backed lithic artefacts; another coherent group of sites where backed bladelets are found; a coherent group or groups of sites where Gravette points are found, or where female figures are found and so on. (In some cases particular types of artefact or other features will appear to be important within a single site but will not have any clear analogies in chronologically and geographically proximate sites. The existence of sui generis features is also important and should also be used to add to our picture of variation within the record as a whole.)

The approach set out here aims to avoid essentialist conceptions of cultural taxonomy by making the use of taxonomic units an entirely optional add-on to the taxonomic framework 
itself. However, by relying on index fossils and other "index features" it does, arguably, continue to take an essentialist view of material culture variation itself, rather than one that is based in population thinking (meant in the philosophical sense, rather than for any relationship with the human populations that are the subject of this chapter; Sober 1980; Leonard and Jones 1987; O'Brien and Holland 1990; Riede 2011). However, it should be noted that the usage of index fossils and features is advocated only as a heuristic tool to link assemblages, rather than as providing anything approaching a full picture of material culture variation. By using many different definitions of index fossils, which are not mutually exclusive, and which vary in their strictness (so that a single artefact can be defined as e.g. both a backed bladelet and as an élément bitronqué), it is hoped that a nuanced, population thinking approach to material culture variation can in fact be approximated, even if strictly speaking the approach advocated here has a different epistemological and methodological basis.

A framework such as the one I describe, which is constructed in a bottom-up fashion directly using links between sites, is ideal for addressing questions of past populations. This framework (which can be characterized as a presence/absence matrix of site and assemblage features, with associated geographical and chronological information) can be analyzed using numerous network analysis methods (e.g. Knappett 2011; Brughmans 2013; Collar et al. 2015) and other statistical methods (e.g. Baxter 2009; Shennan et al. 2015; Rigaud et al. 2018).

We can analyse this data to look for break-points where many different types of material culture changed simultaneously, for slow change over time, for cases where certain types of material culture changed but others didn't. All of these examples have different implications in terms of the cultural and demographic processes that may have caused them. However, material culture can and does change for numerous reasons, many of which are quite 
independent from population changes. The question of the inference of population structure from material culture variation is, therefore, one of the hard problems of prehistoric archaeology in general.

Although there are numerous theoretical approaches that could be applied to this, especially based on ethnographic analogy, for the European Upper Paleolithic we are dealing with very large timescales in the context of significant environmental changes. This makes it very difficult to draw robust analogies from anything that we can observe in the present. In fact, the best way to improve our inference of population structure from the Upper Paleolithic past may be to compare the archaeological record with the results now being obtained from a fundamentally different perspective on prehistory: ancient DNA studies.

\section{Comparing archaeological and paleogenetic evidence}

In recent years several major papers have been published on human genetic diversity during the Upper Paleolithic (e.g. Fu et al. 2016; Posth et al. 2016; Sikora et al. 2017). The results of this work permit direct testing - and improvement - of archaeological inferences regarding Upper Paleolithic population structure.

Some of the results from ancient DNA studies have profound, widespread implications. For example, according to Fu et al. (2016), all analyzed individuals in Europe from between ca. 37,000 cal BP and 14,000 cal BP (or ca. $33,000{ }^{14} \mathrm{C}$ BP and $12,000{ }^{14} \mathrm{C} \mathrm{BP}$ ) "seem to derive from a single ancestral population with no evidence of substantial genetic influx from elsewhere". The spread of Gravettian traditions does appear to have been associated with at least some population movements, as attested by the distribution of the "Věstonice Cluster" that they identify. The dearth of human remains associated with Aurignacian assemblages makes the task of understanding population processes for this part of the archaeological record more difficult. However, an Early Upper Paleolithic individual from Goyet Cave 
belonged to a population that did not disappear with the appearance of Gravettian assemblages, but whose descendants became widespread again during the Late Upper Paleolithic (Fu et al. 2016).

The most significant identified turnover in European populations during the Upper Paleolithic in fact occurred during the Late Upper Paleolithic, 14,500-14,000 cal BP (ca. 12,500-12,000 ${ }^{14} \mathrm{C}$ BP) (Posth et al. 2016; Fu et al. 2016). This does not correlate with a clear and major panEuropean transition in archaeological taxonomic units. If this turnover in populations continues to be supported by further research, it provides a good example of why the current cultural taxonomic framework should not be interpreted as providing a straightforward reflection of past population dynamics.

However, the results from ancient DNA studies do suggest that in some cases, cultural taxonomic transitions were indeed associated with population changes - for example, the Aurignacian-Gravettian transition (albeit not, apparently, associated with a full demographic replacement: Fu et al. 2016; Sikora et al. 2016). Other observations also coincide with archaeological interpretations. For example, Layer I of Kostënki 12 has, despite its Mid Upper Paleolithic age, been consistently described as Gorodtsovian rather than Gravettian due to the composition of its assemblage, which does not contain backed lithics (Sinitsyn 2010, 2015). The attribution of the human remains found at Kostenki 12 to a population that was distinct from the "Věstonice cluster" associated with Gravettian assemblages (Fu et al. 2016; Sikora et al. 2017), suggests that this distinction between Gravettian and Gorodtsovian is well-founded and reflects past population differences.

Genetic data provides an independent line of evidence for comparison against archaeological interpretations (as also argued by Shennan, this volume). In order to strengthen the archaeological understanding of past populations, we can compare our chronocultural 
frameworks against the population histories determined using genetic studies. From such comparisons we can gain an understanding of what types of archaeological evidence and argument can be used for discerning past population dynamics, and how reliable they are. We can then use those same types of evidence and argument in parts of the archaeological record where we have less genetic evidence. Systematic comparison against the results of genetic studies can greatly enhance the archaeological study of Upper Paleolithic populations, and provides an opportunity to move past ad hoc and intuitive reasoning.

None of this is to imply that archaeologists can or should cede the study of the Upper Paleolithic to geneticists. Culture change is fundamentally different from biological genetic change, and we should not expect variation in the archaeological record ever to exactly follow the picture given by genetic data. In fact, it is perhaps in the areas where the results of archaeology and genetics disagree that some of the most interesting future studies will be focused. The purpose of archaeology is not just to describe past populations: it is far more than that. Genetics can give us extraordinarily valuable insights into past populations, but it is archaeology that can make sense of the processes underlying past population dynamics, and the great diversity of associated social and cultural outcomes.

\section{Conclusions}

Population concepts are profoundly important in Upper Paleolithic archaeology, underlying many of our most basic interpretations. However, the present archaeological understanding of Upper Paleolithic populations is far from satisfactory.

We are working within a cultural taxonomic system that has many arbitrary elements and does not provide an accurate overall picture of variation in the Upper Paleolithic archaeological record. In particular, not all taxonomic units are equivalent in their salience or the amount of variation that they encompass. One of the underlying assumptions underlying 
our material culture comparisons and taxonomic unit construction is that they reflect something about sociocultural and population processes. However, an uncritical reading of the conventional Upper Paleolithic taxonomic framework cannot be used to infer the existence of past populations.

Although many of our current taxonomic units do have definite descriptive value, we must treat them as heuristic and revisable, or abandon them altogether. Substantial progress has been made on understanding the full, detailed picture of variation in the archaeological record, although this by necessity tends to be done on relatively small scales. Further comparative work is needed, perhaps especially for the Late Upper Paleolithic record.

The best approaches that we have for improving our chronocultural framework consider both material culture comparison and chronological evidence, the warp and the weft, within a paradigm that expects coherence in the archaeological record itself. A chronocultural framework does not need to consist of abstract, top-down taxonomic units but can instead exist as a formal bottom-up systematization of the individual similarities and differences between sites, as expressed in the presence/absence of particular index features - not only lithic index fossils, but also technological features, personal ornament types, dwelling structure types, and so on. This can be visualized as a network in a chronospatial framework but can also be expressed as matrices recording the co-presence of particular features at different sites, allowing many different types of analyses to be carried out.

Paleogenomics, which in recent years has begun to provide highly interesting results concerning European Upper Paleolithic populations, offers an opportunity to establish some basic principles for the inference of past populations from archaeological data. A chronocultural framework based on a bottom-up examination of archaeological similarities and differences between sites, as proposed here, is ideal for direct comparison against the 
results of genetic studies, which are similarly based on a bottom-up treatment of the similarities and differences between individual genomes. Where archaeology and genetics truly give different pictures of the past (i.e. where this is not just the result of naïve interpretation of cultural taxonomic units) this provides us with an opportunity to gain a fuller understanding of the complexity of cultural change in the past and its differences from biological population change.

At present we are not able to properly evaluate the existence and nature of Upper Paleolithic populations using archaeological evidence, although the occasions where genetic evidence agrees with archaeological data offer intriguing hints that this may, in principle, be possible. However, if we can work at large scales to gain a fuller, more consistent picture of the chronocultural framework for Upper Paleolithic Europe, and if we can systematically compare this framework with the results now being provided by paleogenomic studies, then we have an excellent opportunity to finally establish a solid epistemological basis for the archaeological study of Upper Paleolithic populations. This in turn will greatly enrich our understanding of cultural processes during the Upper Paleolithic and open up new avenues of archaeological interpretation.

The European Upper Paleolithic remains a special case within the Paleolithic as a whole. Not all of the observations made in this chapter are necessarily extensible to the rest of the Paleolithic. Nevertheless, if we can gain a stronger understanding of populations within this small part of the archaeological record, we may perhaps gain insights that can be transferred to the study of other areas and time periods. The study of past populations is at the heart of many of the questions that we ask about the Paleolithic. There are significant theoretical and methodological challenges to be overcome in order to make progress in this area, and correspondingly large gains to be made in our understanding of the human past. 


\section{Acknowledgements}

I am grateful to Will Banks, Julia Kotthaus and Felix Riede for conversations and correspondence that helped me to clarify many of the arguments put forward in this chapter, and to Huw Groucutt for the invitation to contribute to this volume. I also thank the anonymous reviewers and HG for their comments, which were very helpful in improving the manuscript. This work was supported by the European Union's Horizon 2020 research and innovation programme under Marie Skłodowska-Curie grant agreement No 747400. All figures in this chapter were created by NR and are used under a CC-BY 4.0 licence; original figures are available at DOI: 10.17605/OSF.IO/7BU95

\section{References cited}

Abramova, Z. A. (1995). L'art paléolithique d'Europe orientale et de Sibérie. Grenoble: Jérôme Millon.

Abramova, Z. A., Grigorieva, G. V., \& Zaitseva, G. I. (2001). The age of Upper Paleolithic sites in the Middle Dnieper River basin of Eastern Europe. Radiocarbon, 42, 10771084.

Adams, W. Y., \& Adams, E. W. (2009). Archaeological typology and practical reality: A dialectical approach to artifact classification and sorting. Cambridge: Cambridge University Press.

Amirkhanov, Kh. A. (2000). Zaraiskaia stoianka. Moscow: Nauchnyi mir. 
Amirkhanov, Kh. A. (Ed.) (2009). Issledovaniia paleolita v Zaraiske 1999-2005. Moscow: Paleograf.

Amirkhanov, Kh. A., \& Lev, S. Iu. (2008). New finds of Paleolithic art from the Zaraisk site. Anthropology \& Archeology of Eurasia, 46, 24-45.

Anghelinu, M., \& Niţă, L. (2014). What's in a name: The Aurignacian in Romania. Quaternary International, 351, 172-192.

Anghelinu, M., Niţă, L., \& Murătoreanu, G. (2018). Le Gravettien et l'Épigravettien de l'Est de la Roumanie : une réévaluation. L'Anthropologie, 122, 183-219.

Baales, M., Grimm, S., \& Jöris, O. (2001). Hunters of the "Golden Mile": The late Allerød Federmessergruppen Site at Bad Breisig, Central Rhineland, Germany. Notae Praehistoricae, 21, 67-72.

Banks, W. E. (2015). Constructing chronologies for the late Middle Paleolithic and Upper Paleolithic: limitations and means to overcome them. World Archaeology, 47, 585600.

Banks, W. E., d'Errico, F., Townsend Peterson, A., Vanhaeren, M., Kageyama, M., Sepulchre, P., et al. (2008). Human ecological niches and ranges during the LGM in Europe derived from an application of eco-cultural niche modeling. Journal of Archaeological Science, 35, 481-491.

Banks, W. E., d'Errico, F., \& Zilhão, J. (2013a). Human-climate interaction during the Early Upper Paleolithic: testing the hypothesis of an adaptive shift between the ProtoAurignacian and the Early Aurignacian. Journal of Human Evolution, 64, 39-55. 
Banks, W. E., d'Errico, F., \& Zilhão, J. (2013b). Revisiting the chronology of the ProtoAurignacian and the Early Aurignacian in Europe: A reply to Higham et al.'s comments on Banks et al. (2013). Journal of Human Evolution, 65, 810-817.

Barton, C. M. (1997). Stone tools, style, and social identity: an evolutionary perspective on the archaeological record. In C. M. Barton \& G. Clark (Eds.), Rediscovering Darwin: Evolutionary theory and archaeological explanation (pp. 141-156). Washington, DC: Archeological Papers of the American Anthropological Association, No. 7.

Baxter, M. J. (2009). Archaeological data analysis and fuzzy clustering. Archaeometry, 51, $1035-1054$.

Beliaeva, V. I. (2002). Kremnëvaia industriia Pushkarei 1. In N. D. Praslov (Ed.), Verkhnii paleolit - verkhnii pleistotsen: dinamika prirodnykh sobytii $i$ periodizatsiia arkheologicheskikh kul'tur. Materialy mezhdunarodnoi konferentsii, posviashchennoi 90-letiiu so dnia rozhdeniia A. N. Rogachëva (pp. 132-137). Saint Petersburg: Nauka.

Bocquet-Appel, J. P., \& Demars, P. Y. (2000). Population kinetics in the Upper Palaeolithic in western Europe. Journal of Archaeological Science, 27, 551-570.

Bodu, P. (1998). Magdalenians-Early Azilians in the centre of the Paris Basin: a filiation? The example of Le Closeau (Rueil-Malmaison, France). In S. Milliken (Ed.), The organization of lithic technology in Late Glacial and Early Postglacial Europe (BAR International Series 700) (pp. 131-147). Oxford: Oxbow.

Bordes, J.-G. (2006). News from the West: a reevaluation of the classical Aurignacian sequence of the Périgord. In O. Bar-Yosef \& J. Zilhão (Eds.), Towards a definition of the Aurignacian, Proceedings of the Symposium held in Lisbon, Portugal, June 25-30, 
2002 (Trabalhos de Arqueologia 45) (pp. 147-171). Lisbon: Instituto Português de Arqueologia.

Bordes, J.-G., Bachellerie, F., le Brun-Ricalens, F., \& Michel, A. (2011). Towards a new "transition": new data concerning the lithic industries from the beginning of the Upper Palaeolithic in Southwestern France. In A.P. Derevianko \& M. Shunkov (Eds.), Characteristic features of the Middle to Upper Palaeolithic Transition in Eurasia, Proceedings of the International Symposium, "Characteristic features of the Middle to Upper Palaeolithic Transition in Eurasia : Development of Culture and Evolution of Homo Genus" (July 4-10, Denisova Cave, Altai) (pp. 116-129). Novosibirsk: Department of the Institute of Archaeology and Ethnography SB RAS.

Bourrillon, R., White, R., Tartar, E., Chiotti, L., Mensan, R., Clark, A., et al. (2018). A new Aurignacian engraving from Abri Blanchard, France: Implications for understanding Aurignacian graphic expression in Western and Central Europe. Quaternary International, 491, 46-64.

Bradtmöller, M., Pastoors, A., Weninger, B., \& Weniger, G.-C. (2012). The repeated replacement model - Rapid climate change and population dynamics in Late Pleistocene Europe. Quaternary International, 247, 38-49.

Brock, F., \& Higham, T. F. G. (2009). AMS radiocarbon dating of Paleolithic-aged charcoal from Europe and the Mediterranean rim using ABOx-SC. Radiocarbon, 51, 839-846.

Brock, F., Higham, T., Ditchfield, P., \& Bronk Ramsey, C. (2010). Current pretreatment methods for AMS radiocarbon dating at the Oxford Radiocarbon Accelerator Unit (ORAU). Radiocarbon, 52, 103-112. 
Brock, F., Geoghegan, V., Thomas, B., Jurkschat, K., \& Higham, T. F. G. (2013). Analysis of bone "collagen" extraction products for radiocarbon dating. Radiocarbon, 55, 445463.

Brock, F., Dee, M., Hughes, A., Snoeck, C., Staff, R., \& Bronk Ramsey, C. (2018). Testing the effectiveness of protocols for removal of common conservation treatments for radiocarbon dating. Radiocarbon, 60, 35-50.

Bronk Ramsey, C., Higham, T., \& Leach, P. (2004). Towards high-precision AMS: progress and limitations. Radiocarbon, 46, 17-24.

Brughmans, T. (2013). Thinking through networks: a review of formal network methods in archaeology. Journal of Archaeological Method and Theory, 20, 623-662.

Bulochnikova, E. V. (1998). Vchera i segodnia poniatiia "vostochnyi gravet'en". In Kh. A. Amirkhanov (Ed.), Vostochnoi gravett (pp. 67-72). Moscow: Nauchnyi mir.

Bulochnikova, E. V. (2008). Khronologiia verkhnepaleoliticheskikh stoianok v sisteme arkheologicheskikh i estestvennonauchnykh dannykh. In G. A. Khlopachëv (Ed.), Khronologiia, periodizatsiia i krosskul'turnye sviazi v kamennom veke: Zamiatninskii sbornik. Vypusk 1 (pp. 63-73). Saint Petersburg: Nauka.

Burdukiewicz, J. M. (2001). The last Ice Age and settlement break in the northern past of Central Europe. Fontes Archaeologici Posnanienses, 39, 15-29.

Burdukiewicz, J. M. (2011). Late Glacial hunter-gatherer reactions to the Younger Dryas cooling event in the southern and eastern Baltic regions of Europe. Quaternary International, 242, 302-312. 
Burkitt, M., \& Childe, V.G. (1932). A chronological table of prehistory. Antiquity, 6, 185201.

Chu, W., Lengyel, G., Zeeden, C., Péntek, A., Kaminská, L., \& Mester, Z. (2018). Early Upper Paleolithic surface collections from loess-like sediments in the northern Carpathian Basin. Quaternary International, 485, 167-182.

Clark, G. A., \& Riel-Salvatore, J. (2006). Observations on Systematics in Paleolithic Archaeology. In E. Hovers \& S. L. Kuhn (Eds.), Transitions Before the Transition (pp 29-56). Boston, MA: Springer.

Clarke, D. L. (1968). Analytical archaeology (second edition). London: Methuen.

Collar, A., Coward, F., Brughmans, T., \& Mills, B.J. (2015). Networks in archaeology: phenomena, abstraction, representation. Journal of Archaeological Method and Theory, 22, 1-32.

Collard, M., Shennan, S. J., Buchanan, B., \& Bentley, R.A. (2009). Evolutionary biological methods and cultural data. In R.A. Bentley, H. D. G. Maschner \& C. Chippindale (Eds.), Handbook of Archaeological Theories (pp. 203-223). Lanham: Altamira Press.

Collie, G. L. (1928). The Aurignacians and their culture. Beloit: Logan Museum.

Conard, N. J., \& Bolus, M. (2003). Radiocarbon dating the appearance of modern humans and timing of cultural innovations in Europe: new results and new challenges. Journal of Human Evolution, 44, 331-371. 
de la Peña, P., \& Vega Toscano, G. (2013). The Early Upper Palaeolithic puzzle in Mediterranean Iberia. Quartär, 60, 85-106.

Demars, P.-Y. (1990). Proposition pour une nouvelle liste typologique des outillages lithiques du Paléolithique supérieur. Paléo, 2, 191-201.

Demars, P.-Y., \& Laurent, P. (1992). Types d'outils lithiques du Paléolithique supérieur en Europe. Paris: Presses du CNRS.

d'Errico, F., \& Banks, W. E. (2015). Tephra studies and the reconstruction of Middle-toUpper Paleolithic cultural trajectories. Quaternary Science Reviews, 118, 182-193.

de Sonneville-Bordes, D. (1966). L'évolution du Paléolithique supérieur en Europe occidentale et sa signification. Bulletin de la Société préhistorique française, 63, 334.

de Sonneville Bordes, D., \& Perrot, J. (1954). Lexique typologique du Paléolithique supérieur. Bulletin de la Société préhistorique française, 51, 327-335.

de Sonneville Bordes, D., \& Perrot, J. (1955). Lexique typologique du Paléolithique supérieur. Bulletin de la Société préhistorique française, 52, 76-79.

de Sonneville Bordes, D., \& Perrot, J. (1956a). Lexique typologique du Paléolithique supérieur. Bulletin de la Société préhistorique française, 53, 408-412.

de Sonneville Bordes, D., \& Perrot, J. (1956b). Lexique typologique du Paléolithique supérieur. Bulletin de la Société préhistorique française, 53, 547-559. 
Deviese, T., Comeskey, D., McCullagh, J., Bronk Ramsey, C., \& Higham, T. (2018). New protocol for compound-specific radiocarbon analysis of archaeological bones. Rapid Communications in Mass Spectrometry, 32, 373-379.

Dibble, H. L. 1995. Middle Paleolithic scraper reduction: background, clarification, and review of the evidence to date. Journal of Archaeological Method and Theory, 2, 299-368.

Dibble, H. L., Holdaway, S. J., Lin, S. C., Braun, D. R., Douglass, M. J., Iovita, R., et al. (2016). Major fallacies surrounding stone artifacts and assemblages. Journal of Archaeological Method and Theory, 24, 813-851.

Dinnis, R., Bessudnov, A., Reynolds, N., Devièse, T., Pate, A., Sablin, M., et al. (2019). New data for the Early Upper Paleolithic of Kostenki (Russia). Journal of Human Evolution, 127, 21-40.

Discamps, E., Gravina, B., \& Teyssandier, N. (2015) In the eye of the beholder: contextual issues for Bayesian modelling at the Middle-to-Upper Palaeolithic transition. World Archaeology, 47, 601-621.

Djindjian, F. (2016). Territories and economies of hunter-gatherer groups during the last glacial maximum in Europe. Quaternary International, 412, 37-43.

Djindjian, F., Kozlowski, J., \& Otte, M. (1999). Le Paléolithique supérieur en Europe. Paris: Armand Colin.

Dobres, M.-A. (1999). Technology's links and chaînes: the processual unfolding of technique and technician. In M.-A. Dobres \& C. R. Hoffman (Eds.), The social dynamics of 
technology: practice, politics, and world views (pp. 124-146). Washington, D.C: Smithsonian Institution Press.

Doyon, L. (2019). On the shape of things: A geometric morphometrics approach to investigate Aurignacian group membership. Journal of Archaeological Science, 101, 99-114.

Ducasse, S. (2012). What is left of the Badegoulian "interlude"? New data on cultural evolution in southern France between 23,500 and 20,500 cal. BP. Quaternary International, 272-273, 150-165.

Ducasse, S., \& Langlais, M. (2007). Entre Badegoulien et Magdalénien, nos coeurs balancent... Approche critique des industries lithiques du Sud de la France et du Nord-Est espagnol entre 19000 et 16500 BP. Bulletin de la Société préhistorique française, 104, 771-785.

Dunnell, R. C. (1971). Systematics in prehistory. New York: Free Press.

Dunnell, R. C. (1986). Methodological issues in Americanist artifact classification. Advances in Archaeological Method and Theory, 9, 149-207.

Efimenko, P. P. (1958). Kostënki I. Moscow: Izdatel'stvo Akademii Nauk SSSR.

Es'kova, D. K. (2015). Tekhnologiia rasshchepleniia kamnia na stoiankakh vostochnogo gravetta Russkoi ravniny. Ph.D Dissertation avtoreferat, Institut Arkheologii RAN, Moscow.

Fat Cheung, C., Chevallier, A., Bonnet-Jacquement, P., Langlais, M., Ferrié, J.-G., Costamagno, S., et al. (2014). Comparaison des séquences aziliennes entre Dordogne 
et Pyrénées: état des travaux en cours. In M. Langlais, N. Naudinot \& M. Peresani (Eds.), Les groupes culturels de la transition Pléistocène-Holocène entre Atlantique et Adriatique. Actes de la séance de la Société préhistorique française de Bordeaux, 2425 mai 2012 (pp. 17-44). Paris: Société préhistorique française.

Finlayson, C., \& Carrión, J. S. (2007). Rapid ecological turnover and its impact on Neanderthal and other human populations. TRENDS in Ecology and Evolution, 22, $213-222$.

French, J. C. (2015). The demography of the Upper Palaeolithic hunter-gatherers of Southwestern France: A multi-proxy approach using archaeological data. Journal of Anthropological Archaeology, 39, 193-209.

Frouin, M., Guérin, G., Lahaye, C., Mercier, N., Huot, S., Aldeias, V., Bruxelles, L., Chiotti, L., Dibble, H. L., Goldberg, P., Madelaine, S., McPherron, S. J. P., Sandgathe, D., Steele, T. E., \& Turq, A. (2017). New luminescence dating results based on polymineral fine grains from the Middle and Upper Palaeolithic site of La Ferrassie (Dordogne, SW France). Quaternary Geochronology, 39, 131-141.

Fu, Q., Posth, C., Hajdinjak, M., Petr, M., Mallick, S., Fernandes, D., et al. (2016). The genetic history of Ice Age Europe. Nature, 534, 200-205.

Gamble, C., Davies, W., Pettitt, P., Hazelwood, L., \& Richards, M. (2005). The archaeological and genetic foundations of the European population during the Late Glacial: implications for 'agricultural thinking'. Cambridge Archaeological Journal, $15,193-223$. 
Garrod, D. A. E. (1938). The Upper Palaeolithic in the light of recent discovery. Proceedings of the Prehistoric Society, 4, 1-26.

Gaudzinski-Windheuser, S., \& Jöris, O. (2015). Contextualising the female image - symbols for common ideas and communal identity in Upper Palaeolithic societies. In F. Coward, R. Hosfield, M. Pope \& F. Wenban-Smith (Eds.), Settlement, society and cognition in human evolution: Landscapes in mind (pp. 288-314). Cambridge: Cambridge University Press.

Gavrilov, K. N. (2016). Verkhnii paleolit basseina Desny: preemstvennost' $i$ variabel'nost'v razvitii material'noi kul'tury. Moscow: Nestor-Istoriia.

Gavrilov, K. N., Voskresenskaya, E. V., Maschenko, E. N., \& Douka, K. (2015). East Gravettian Khotylevo 2 site: Stratigraphy, archeozoology, and spatial organization of the cultural layer at the newly explored area of the site. Quaternary International, $359-360,335-346$.

Goutas, N. (2013). De Brassempouy À Kostienki : l'exploitation technique des ressources animales dans l'Europe gravettienne. In M. Otte (Ed.), Les Gravettiens (pp. 105-160). Paris: Éditions Errance.

Goutas, N. (2016). Gravettian projectile points: Considerations about the evolution of osseous hunting weapons in France. In M. Langley (Ed.), Osseous Projectile Weaponry (pp. 89-107). Dordrecht: Springer.

Gravina, B., Bachellerie, F., Caux, S., Discamps, E., Faivre, J.-P., Galland, A., et al. (2018). No reliable evidence for a Neanderthal-Châtelperronian association at La Roche-àPierrot, Saint-Césaire. Scientific Reports, 8, 15134. 
Grigor'ev, G. P. (1993). The Kostenki-Avdeevo archaeological culture and the WillendorfPavlov-Kostenki-Avdeevo cultural unity. In O. Soffer \& N. D. Praslov (Eds.), From Kostenki to Clovis: Upper Paleolithic - Paleo-Indian Adaptations (pp. 51-65). New York: Plenum Press.

Grimm, S. B., \& Weber, M.-J. (2008). The chronological framework of the Hamburgian in the light of old and new ${ }^{14} \mathrm{C}$ dates. Quartär, 55, 17-40.

Groucutt, H.S. (this volume). Culture and convergence: The curious case of the Nubian Complex. In: H. Groucutt (Ed.), Culture History and Convergent Evolution: Can we Detect Populations in Prehistory? (pp. x). Springer, Cham, Switzerland.

Gvozdover, M. V. (1998). Kremnëvyi inventar’ Avdeevskoi verkhnepaleoliticheskoi stoianki. In K. A. Amirkhanov (Ed.), Vostochnoi gravett (pp. 234-278). Moscow: Nauchnyi mir.

Haesaerts, P., Damblon, F., Nigst, P., \& Hublin, J.-J. (2013). ABA and ABOx radiocarbon cross-dating on charcoal from Middle Pleniglacial loess deposits in Austria, Moravia, and western Ukraine. Radiocarbon, 55, 641-647.

Haesaerts, P., Damblon, F., van der Plicht, J., Otte, M., \& Nigst, P. R. (2017). Additional data to the stratigraphy and the chronology of the Kostenki 1 (Poliakov) sequence, Voronezh, Russia. In S. Vasilyev, A. Sinitsyn \& M. Otte (Eds.), Le Sungirien, SaintPétersbourg 2016 (pp. 135-142). Liège: ÉRAUL 147.

Hahn, J. (1988). Die Geißenklösterle-Höhle im Achtal bei Blaubeuren I. Fundhorizontbildung und Besiedlung im Mittelpalaölithikum und im Aurignacien. Stuttgart: Konrad Theiss Verlag. 
Harrold, F. B. (1993). Variability and function among Gravette points from southwestern France. Archeological Papers of the American Anthropological Association, 4, 69-81.

Hayden, B. (1984). Are Emic Types Relevant to Archaeology? Ethnohistory, 31, 79-92.

Hays, M. A., \& Lucas, G. (2000). A technological and functional analysis of carinates from Le Flageolet I, Dordogne, France. Journal of Field Archaeology, 27, 455-465.

Hermon, S., \& Niccolucci, F. (2017). Formally defining the time-space-archaeological culture relation: Problems and prospects. Archeologia e Calcolatori, 28, 93-108.

Higham, T. F. G. (2011). European Middle and Upper Palaeolithic radiocarbon dates are often older than they look: problems with previous dates and some remedies. Antiquity, 85, 235-249.

Higham, T., Basell, L., Jacobi, R., Wood, R., Bronk Ramsey, C., \& Conard, N. J. (2012). Testing models for the beginnings of the Aurignacian and the advent of figurative art and music: The radiocarbon chronology of Geißenklösterle. Journal of Human Evolution, 62, 664-676.

Higham, T., Wood, R., Moreau, L., Conard, N., \& Bronk Ramsey, C. (2013). Comments on 'Human-climate interaction during the early Upper Paleolithic: Testing the hypothesis of an adaptive shift between the Proto-Aurignacian and the Early Aurignacian' by Banks et al. Journal of Human Evolution, 65, 806-809.

Hřdlicka, A. (1927). The Neanderthal phase of man. The Journal of the Royal Anthropological Institute of Great Britain and Ireland, 57, 249-274. 
Hromadova, B. (2012). Ispol'zovanie syr'ia iz kosti, bivnia $i$ roga na stoiankakh kostënkovsko-avdeevskoi kul'tury (vostochnoi gravett). Ph.D. Dissertation avtoreferat, MGU, Moscow.

Hublin, J. J. (2015). The modern human colonization of western Eurasia: when and where? Quaternary Science Reviews, 118, 194-210.

Hurt, T. D., \& Rakita, G. F. M. (Eds.) (2001) Style and function: Conceptual issues in evolutionary archaeology. Westport, CT: Bergin \& Garvey.

Iakovleva, L. (2003). Les habitats en os de mammouths du Paléolithique supérieur d'Europe orientale : les données et leur interprétation. In S. A. Vasiliev, O. Soffer \& J. K. Kozłowski (Eds.), Perceived landscapes and built environments: the cultural geography of late palaeolithic Eurasia. Actes du XIV Congrès UISPP, Université de Liège, Belgique, 2-8 septembre 2001 : colloques $6.2 \& 6.5$ (BAR International Series 1122) (pp. 47-57). Oxford: Oxbow Books.

Ivanova, M. A. (1985). Struktura Gmelinskogo paleoliticheskogo poselniia (po rezul'tatam planigraficheskogo i tipologicheskogo analiza kremnëvogo inventaria). Ph.D Dissertation avtoreferat, LOIA RAN, Leningrad.

Jordan, P. (2015). Technology as human social tradition: Cultural transmission among hunter-gatherers. Oakland: University of California Press.

Khlopachev, G., Vercoutère, C., \& Wolf, S. (2018). Les statuettes féminines en ivoire des faciès gravettiens et post-gravettiens en Europe centrale et orientale : modes de fabrication et de représentation. L'anthropologie, 122, 492-521. 
Klaric, L. (2007). Regional groups in the European Middle Gravettian: a reconsideration of the Rayssian technology. Antiquity, 81, 176-190.

Klaric, L., Guillermin, P., \& Aubry, T. (2009). Des armatures variées et des modes de productions variables. Gallia Préhistoire, 51, 113-154.

Klaric, L., Lev, S., Giria, Y., \& Polanská, M. (2015). 'Couteaux de Kostienki et lames aménagées par technique de Kostienki’. Retour sur un malentendu historique. Bulletin de la Société préhistorique française, 112, 421-474.

Knappett, C. (2011). An archaeology of interaction: Network perspectives on material culture and society. Oxford: Oxford University Press.

Kozłowski, J. K. (2015). The origin of the Gravettian. Quaternary International, 359, 3-18.

Kramer, C. (1977). Pots and People. In L. D. Levine and T. C. Young (Eds.), Mountains and Lowlands: Essays in the Archaeology of Greater Mesopotamia (pp. 91-112). Malibu: Undena Publications.

Lacarrière, J., Goutas, N., Normand, C., Simonet, A., \& Schwab, C. (2011). Vers une redéfinition des occupations gravettiennes de la grotte d'Isturitz (PyrénéesAtlantiques, France) : révision critique des collections «anciennes » par l'approche intégrée des données lithiques, fauniques et de l'industrie osseuse. In N. Goutas, L. Klaric, D. Pesesse \& P. Guillermin (Eds.), À la recherche des identités gravettiennes : actualités, questionnements et perspectives : actes de la table ronde sur le Gravettien en France et dans les pays limitrophes, Aix-en-Provence, 6-8 octobre 2008 (Mémoire SPF 52) (pp. 67-83). Paris: Société préhistorique française. 
Langlais, M., Sécher, A., Caux, S., Delvigne, V., Gourc, L., Normand, C., et al. (2016). Lithic tool kits: A metronome of the evolution of the Magdalenian in southwest France (19,000-14,000 cal BP). Quaternary International, 414, 92-107.

Leonard, R.D., \& Jones, G.T. (1987). Elements of an inclusive evolutionary model for archaeology. Journal of Anthropological Archaeology, 6, 199-219.

Le Brun-Ricalens, F., Bordes, J.-G., \& Eizenberg, L. (2009). A crossed-glance between southern European and Middle-Near Eastern early Upper Palaeolithic lithic technocomplexes. Existing models, new perspectives. In M. Camps \& C. Szmidt (Eds.), The Medterranean from 50000 to 25000 BP: Turning points and new directions (pp. 11-33). Oxford: Oxbow Books.

Lengyel, G. (2016). Reassessing the Middle and Late Upper Palaeolithic in Hungary. Acta Archaeologica Carpathica, 51, 47-66.

Leroi-Gourhan A. (1964-1965). Le geste et la parole, vols. 1 and 2. Paris: A. Michel.

Lev, S. Y. (2009). Kamennyi inventar' Zaraiskoi stoianki: Tipologicheskii aspekt. In K. A. Amirkhanov (Ed.), Issledovaniia paleolita v Zaraiske 1999-2005 (pp. 37-185). Moscow: Paleograf.

Lev, S. Y., Klarik, L., \& Giria, E. Y. (2011). Nozhi kostënkovskogo tipa i plastiny s podrabotkoi kontsa: fenomen konvergentnogo razvitiia ili rodstvo tekhnologii? In K. N. Gavrilov (Ed.), Paleolit i mezolit vostochnoi Evropy (pp. 235-279). Moscow: Institut arkheologii RAN/Taus. 
Lisitsyn, S. N. (1998). Mikroplastinchatyi inventar' verkhnego sloia Kostënok 1 i nekotorye problemy razvitiia mikroorudii $\mathrm{v}$ verkhnem paleolite Russkoi ravniny. In Kh. A. Amirkhanov (Ed.), Vostochnoi gravett (pp. 299-308). Moscow: Nauchnyi mir.

Lisitsyn, S. N. (2015). The late Gravettian of Borshevo 5 in the context of the KostenkiBorshevo sites (Don basin, Russia). Quaternary International, 359-60, 372-383.

Lomax, J., Fuchs, M., Preusser, F., \& Fiebig, M. (2014). Luminescence based loess chronostratigraphy of the Upper Palaeolithic site Krems-Wachtberg, Austria. Quaternary International, 351, 88-97.

Lyman, R. L., \& O'Brien, M. J. (2004). A History of Normative Theory in Americanist Archaeology. Journal of Archaeological Method and Theory, 11, 369-396.

Macalister, R. A. S. (1921). A text-book of European archaeology. Vol. I: The Palaeolithic period. Cambridge: Cambridge University Press.

MacCurdy, G. G. (1914). La Combe, a Paleolithic cave in the Dordogne. American Anthropologist, 16, 157-184.

MacCurdy, G. G. (1915). [Book Review] Ancient Hunters and their Modern Representatives. By WJ Sollas, D. Sc., FRS, Professor of Geology and Palaeontology in the University of Oxford. Second Edition. The American Historical Review, 21, 135-137.

Maher, L.A., Macdonald, D.A. (this volume). Communities of interaction: Tradition and learning in stone tool production through the lens of the Epipaleolithic of Khareh IV, Jordan. In: H. Groucutt (Ed.), Culture History and Convergent Evolution: Can we Detect Populations in Prehistory? (pp. x). Springer, Cham, Switzerland. 
Maier, A. (2015). The central European Magdalenian: Regional diversity and internal variability. Dordrecht: Springer.

Marks, A. E., Hietala, H. J., \& Williams, J. K. (2001). Tool standardization in the Middle and Upper Palaeolithic: a closer look. Cambridge Archaeological Journal, 11, 17-44.

Marom, A., McCullagh, J. S. O., Higham, T. F. G., Sinitsyn, A. A., \& Hedges, R. E. M. (2012). Single amino acid radiocarbon dating of Upper Paleolithic modern humans. Proceedings of the National Academy of Sciences of the USA, 109, 6878-6881.

Marom, A., McCullagh, J. S. O., Higham, T. F. G., \& Hedges, R. E. M. (2013). Hydroxyproline dating: experiments on the ${ }^{14} \mathrm{C}$ analysis of contaminated and lowcollagen bones. Radiocarbon, 55, 698-708.

McCullagh, J. S. O., Marom, A., \& Hedges, R. E. M. (2010). Radiocarbon dating of individual amino acids from archaeological bone collagen. Radiocarbon, 52, 620634.

McNabb, J. (this volume). Problems and pitfalls in understanding the Clactonian. In: H. Groucutt (Ed.), Culture History and Convergent Evolution: Can we Detect Populations in Prehistory? (pp. x). Springer, Cham, Switzerland.

Mellars, P. (1989). Major issues in the emergence of modern humans. Current Anthropology, $30,349-385$.

Mesoudi, A., \& O'Brien, M. J. (2009). Placing archaeology within a unified science of cultural evolution. In S. Shennan (Ed.), Pattern and process in cultural evolution (pp. 21-32). Berkeley: University of California Press. 
Michel, A. (2010). L'Aurignacien récent (post-ancien) dans le Sud-Ouest de la France: variabilité des productions lithiques. Révision taphonomique et techno-économique des sites de Caminade-Est, abri Pataud, Roc-de-Combe, Le Flageolet I, La Ferrassie et Combemenue. Ph.D. Dissertation, Université de Bordeaux.

Mihailovic, D., \& Mihailovic, B. (2007). Considérations sur le Gravettien et l'Épigravettien ancien des Balkans de l'ouest. Paléo, 19, 115-128.

Moreau, L. (2010). Geißenklösterle. The Swabian Gravettian in its European context. Quartär, 57, 79-93.

Morin, E., Tsanova, T., Sirakov, N., Rendu, W., Mallye, J.-B., \& Lévêque, F. (2005). Bone refits in stratified deposits: testing the chronological grain at Saint-Césaire. Journal of Archaeological Science, 32, 1083-1098.

Mussi, M., Cinq Mars, J., \& Bolduc, P. (2000). Echoes from the mammoth steppe: the case of the Balzi Rossi. In W. Roebroeks, M. Mussi, J. Svoboda \& K. Fennema (Eds.), Hunters of the Golden Age (pp. 105-124). Leiden: University of Leiden Press.

Nalawade-Chavan, S., McCullagh, J., \& Hedges, R. (2014). New hydroxyproline radiocarbon dates from Sungir', Russia, confirm early Mid Upper Palaeolithic burials in Eurasia. PLoS ONE, 9, e76896.

Naudinot, N., Tomasso, A., Messager, E., Finsinger, W., Ruffaldi, P., \& Langlais, M. (2017). Between Atlantic and Mediterranean: Changes in technology during the Late Glacial in Western Europe and the climate hypothesis. Quaternary International, 428 (B), $33-49$. 
Neeley, M.P., \& Barton, C.M. (1994). A new approach to interpreting late Pleistocene microlith industries in southwest Asia. Antiquity, 68, 275-288.

Nigst, P. R., Haesaerts, P., Damblon, F., Frank-Fellner, C., Mallol, C., Viola, B., et al. (2014). Early modern human settlement of Europe north of the Alps occurred 43,500 years ago in a cold steppe-type environment. PNAS, 111, 14394-14399.

Noiret, P. (2009). Le Paléolithique supérieur de Moldavie. Essai de synthèse d'une évolution multi-culturelle. Liège: ÉRAUL 121.

Noiret, P. (2013). De quoi Gravettien est-il le nom ? In M. Otte (Ed.), Les Gravettiens (pp. 29-64). Paris: Éditions Errance.

O’Brien, M., Holland, T.D. (1990). Variation, selection, and the archaeological record. Archaeological Method and Theory, 2, 31-79.

O’Brien, M.J., Bentley, R.A. (this volume). Learning strategies and population dynamics during the Pleistocene colonization of North America. In: H. Groucutt (Ed.), Culture History and Convergent Evolution: Can we Detect Populations in Prehistory? (pp. x). Springer, Cham, Switzerland.

Odell, G. (1981). The morphological express at function junction: Searching for meaning in lithic tool types. Journal of Anthropological Research, 37, 319-342.

Otte, M. (1981). Le Gravettien en Europe Centrale. Bruges: De Tempel (Dissertationes Archaeologicae Gandenses, vol. XX).

Otte, M. (Ed.) (2010). Les Aurignaciens. Paris: Éditions Errance.

Otte, M. (Ed.) (2013). Les Gravettiens. Paris: Éditions Errance. 
Paris, C., Deneuve, E., Fagnart, J.-P., Coudret, P., Antoine, P., Peschaux, C., et al. (2017). Premières observations sur le gisement gravettien à statuettes féminines d'AmiensRenancourt 1 (Somme). Bulletin de la Société préhistorique française, 114, 423-444.

Pelegrin, J. (1991). Les savoir-faire : une très longue histoire. Terrain, 16, 106-113.

Pelegrin, J. (2007). Réflexions sur la notion de spécialiste dans la taille de la pierre au Paléolithique. In R. Desbrosse \& A. Thévenin (Eds.), Arts et cultures de la Préhistoire: hommages à Henri Delporte (pp. 315-318). Paris: Éditions du Comité des travaux historiques et scientifiques.

Pelegrin, J. (2012). Sur les débitages laminaires du Paléolithique supérieur. In F. Delpech \& J. Jaubert (Eds.), François Bordes et la Préhistoire: colloque international François Bordes, Bordeaux, 22-24 avril 2009 (pp. 141-152). Paris: Éditions du Comité des Travaux historiques et scientifiques.Perlès, C. (2013). Tempi of change: when soloists don't play together. Arrhythmia in 'continuous' change. Journal of Archaeological Method and Theory, 20, 281-299.

Pesesse, D. (2013). Le Gravettien existe-t-il ? Le prisme du système technique lithique. In M. Otte (Ed.), Les Gravettiens (pp. 67-104). Paris: Éditions Errance.

Pesesse, D. (2009-2010). La pointe de Font-Yves et les productions lithiques des derniers Aurignaciens. Paléo, 21, 203-222.

Pesesse, D., \& Michel, A. (2006). Le burin des Vachons: apports d'une relecture technologique à la compréhension de l'Aurignacien final. Paléo, 18, 143-160. 
Pigeot, N. (1990). Technical and social actors in Prehistory. Flintknapping specialists and apprentices at Magdalenian Étiolles. Archaeological Review from Cambridge, 9, 126141.

Polanská, M., \& Hromadová, B. (2015). Réflexion autour des industries gravettiennes « postpavloviennes » de Slovaquie occidentale et de Moravie (25,500/24,500-22,000 BP non calibré). In S. Sázelová, M. Novák \& A. Mizerová (Eds.), Forgotten times and spaces: New perspectives in paleoanthropological, paleoetnological and archeological studies (pp. 132-154). Brno: Institute of Archeology of the Czech Academy of Sciences and Masaryk University.

Posth, C., Renaud, G., Mittnik, A., Drucker, D. G., Rougier, H., Cupillard, C., et al. (2016). Pleistocene mitochondrial genomes suggest a single major dispersal of non-Africans and a Late Glacial population turnover in Europe. Current Biology, 26, 827-833.

Praslov, N. D., \& Ivanova, M. A. (1982). Kostënki 21 (Gmelinskaia stoianka). In N. D. Praslov \& A. N. Rogachëv (Eds.), Paleolit kostënkovsko-borshchëvskogo raiona na Donu 1879-1979: Nekotorye itogi polevykh issledovanii (pp. 198-210). Leningrad: Nauka.

Read, D. W. (1989). Intuitive typology and automatic classification: divergence or full circle? Journal of Anthropological Archaeology, 8, 158-188.

Renard, C. (2011). Continuity or discontinuity in the Late Glacial Maximum of south-western Europe: the formation of the Solutrean in France. World Archaeology, 43, 726-743. 
Reynolds, N. (2014). The Mid Upper Palaeolithic of European Russia: chronology, culture history and context. A study of five Gravettian backed lithic assemblages. Ph.D. Dissertation, University of Oxford.

Reynolds, N. (Accepted manuscript). The Gravettian is dead: against equivocation and reification in chronocultural studies of the Upper Palaeolithic. Submitted to N. Goutas, P. Noiret, H. Salomon \& O. Touzé (Eds.), North-Western Europe during the Gravettian: Contributions of recent research to the understanding of the societies and their environments (proceedings of a conference held at the Université de Liège, 12-13 April 2018). Liège: ÉRAUL.

Reynolds, N., \& Green, C. (2019). Spatiotemporal modelling of radiocarbon dates using linear regression does not indicate a vector of demic dispersal associated with the earliest Gravettian assemblages in Europe. Journal of Archaeological Science: Reports, 27, 101958.

Reynolds, N., Lisitsyn, S. N., Sablin, M. V., Barton, N., \& Higham, T. (2015). Chronology of the European Russian Gravettian: new radiocarbon dating results and interpretation. Quartär, 62, 121-32.

Reynolds, N., Dinnis, R., Bessudnov, A. A., Devièse, T., \& Higham, T. F. G. (2017). The Kostënki 18 child burial and the cultural and funerary landscape of Mid Upper Palaeolithic European Russia. Antiquity, 91, 1435-1450.

Reynolds, N., Germonpré, M., Bessudnov, A. A., \& Sablin, M. V. (2019). The Late Gravettian site of Kostënki 21 Layer III, Russia: a chronocultural reassessment based on a new interpretation of the significance of intra-site spatial patterning. Journal of Paleolithic Archaeology, in press. 
Riede, F. (2011). Steps towards operationalizing an evolutionary archaeological definition of culture. In B. W. Roberts \& M. Vander Linden (Eds.), Investigating archaeological cultures: Material culture, variability, and transmission (pp. 245-270). New York: Springer.

Riel-Salvatore, J., \& Clark, G. A. (2001). Grave markers: Middle and Early Upper Paleolithic burials and the use of chronotypology in contemporary Paleolithic research. Current Anthropology, 42, 449-479.

Rigaud, S., Roussel, M., Rendu, W., Primault, J., Renou, S., Hublin, J.-J., et al. (2014). Les pratiques ornementales à l'Aurignacien ancien dans le Centre-Ouest de la France. L'apport des fouilles récentes aux Cottés (Vienne). Bulletin de la Société préhistorique française, 111, 19-38.

Rigaud, S., Manen, C., \& García-Martínez de Lagrán, I. (2018). Symbols in motion: Flexible cultural boundaries and the fast spread of the Neolithic in the western Mediterranean. PLoS ONE, 13, e0196488.

Roberts, B. W., \& Vander Linden, M. (2011). Investigating archaeological cultures: Material culture, variability, and transmission. In B. W. Roberts \& M. Vander Linden (Eds.), Investigating archaeological cultures: Material culture, variability, and transmission (pp. 1-21). New York: Springer.

Rogachëv, A. N. (1957). Mnogosloinye stoianki kostënkovsko-borshëvskogo raiona na Donu i problema razvitiia kul'tury $\mathrm{v}$ epokhu verkhnego paleolita na Russkoi ravnine. Materialy i issledovaniia po arkheologii SSSR, 59, 9-134. 
Rogachëv, A. N., \& Anikovich, M. V. (1982). Kostënki 9 (Biriuch'ii Log). In N. D. Praslov \& A. N. Rogachëv (Eds.), Paleolit kostënkovsko-borshchëvskogo raiona na Donu 1879-1979: Nekotorye itogi polevykh issledovanii (pp. 109-113). Leningrad: Nauka.

Rogachëv, A. N., \& Popov, V. V. (1982). Kostënki 11 (Anosovka 2). In N. D. Praslov \& A. N. Rogachëv (Eds.), Paleolit kostënkovsko-borshchëvskogo raiona na Donu 18791979: Nekotorye itogi polevykh issledovanii (pp. 116-132). Leningrad: Nauka.

Ronchitelli, A., Mugnaini, S., Arrighi, S., Atrei, A., Capecchi, G., Giamello, M., et al. (2015). When technology joins symbolic behaviour: The Gravettian burials at Grotta Paglicci (Rignano Garganico - Foggia - Southern Italy). Quaternary International, 359-360, $423-441$

Sackett, J. R. (1982). Approaches to style in lithic archaeology. Journal of Anthropological Archaeology, 1, 59-112.

Sackett, J. R. (1985). Style and ethnicity in the Kalahari: A reply to Wiessner. American Antiquity, 50, 154-159.

Sauer, F., \& Riede, F. (2018). A critical reassessment of cultural taxonomies in the Central European Late Palaeolithic. Journal of Archaeological Method and Theory. DOI: $10.1007 / \mathrm{s} 10816-018-9368-0$

Scerri, E. M. L., Drake, N. A., Jennings, R., \& Groucutt, H. S. (2014). Earliest evidence for the structure of Homo sapiens populations in Africa. Quaternary Science Reviews, $101,207-216$. 
Schmidt, I., Bradtmöller, M., Kehl, M., Pastoors, A., Tafelmaier, Y., Weninger, B., et al. (2012). Rapid climate change and variability of settlement patterns in Iberia during the Late Pleistocene. Quaternary International, 274, 179-204.

Schwabedissen, H. (1954). Die Federmesser-Gruppen des nordwesteuropäischen Flachlandes: Zur Ausbreitung des Spät-Magdalénien (Offa-Bücher 9). Neumünster: Karl Wachholtz Verlag.

Serwatka, K., \& Riede, F. (2016). 2D geometric morphometric analysis casts doubt on the validity of large tanged points as cultural markers in the European Final Palaeolithic. Journal of Archaeological Science: Reports, 9, 150-159.

Shea, J. J. (2014). Sink the Mousterian? Named stone tool industries (NASTIES) as obstacles to investigating hominin evolutionary relationships in the Later Middle Paleolithic Levant. Quaternary International, 350, 169-179.

Shennan, S. (this volume). Style, function and cultural transmission. In: H. Groucutt (Ed.), Culture History and Convergent Evolution: Can we Detect Populations in Prehistory? (pp. x). Springer, Cham, Switzerland.

Shennan, S. J., Crema, E. R., \& Kerig, T. (2015). Isolation-by-distance, homophily, and "core" vs. "package" cultural evolution models in Neolithic Europe. Evolution and Human Behavior, 36, 103-109.

Sikora, M., Seguin-Orlando, A., Sousa, V. C., Albrechtsen, A., Korneliussen, T., Ko, A., et al. (2017). Ancient genomes show social and reproductive behavior of early Upper Paleolithic foragers. Science, 358, 659-662. 
Simonet, A. (2012). Brassempouy (Landes, France) ou la matrice gravettienne de l'Europe. Liège: ÉRAUL 133.

Sinitsyn, A. A. (2007). Variabilité du Gravettien de Kostienki (bassin moyen du Don) et des territoires associés. Paléo, 19, 181-202.

Sinitsyn, A. A. (2010). The Early Upper Palaeolithic of Kostenki: Chronology, Taxonomy, and Cultural Affiliation. In C. Neugebauer-Maresch \& L. R. Owen (Eds.), New Aspects of the Central and Eastern European Upper Palaeolithic - methods, chronology, technology and subsistence (Symposium by the Prehistoric Commission of the Austrian Academy of Sciences, Vienna, November 9-11, 2005) (pp. 27-48). Vienna: Österreichischen Akademie der Wissenschaften.

Sinitsyn, A. A. (2013). Gravett Kostënok v kontekste gravetta Vostochnoi Evropy. In G. V. Sinitsyna (Ed.), Problemy zaseleniia severo-zapada Vostochnoi Evropy v verkhnem $i$ final'nom paleolite (kul'turno-istoricheskie protsessy) (pp. 4-32). Saint Petersburg: IIMK RAN.

Sinitsyn, A. A. (2014). K probleme kul'turnoi prinadlezhnosti Pushkarei 1. In D. G. Savinov \& A. I. Murashkin (Eds.), Problemy arkheologii epokhi kamnia: $k$ 70-letiiu Valentiny Ivanovny Beliaevoi: Sbornik nauchnykh statei (Trudy istoricheskogo fakul'teta SPbGU, vol. 18) (pp. 234-244). Saint Petersburg: Izdatel'stvo SPbGU.

Sinitsyn, A. A. (2015). Perspectives on the Palaeolithic of Eurasia: Kostënki and related sites. In N. Sanz (Ed.), Human origin sites and the World Heritage Convention in Eurasia, vol. 1 (HEADS 4) (pp. 163-189). Paris \& Mexico City: UNESCO. 
Sinitsyn, A. A., Praslov, N. D., Svezhentsev, Iu. S., \& Sulerzhitskii, L. D. (1997). Radiouglerodnaia khronologiia verkhnego paleolita Vostochnoi Evropy. In A. A. Sinitsyn \& N. D. Praslov (Eds.), Radiouglerodnaia khronologiia paleolita Vostochnoi Evropy i Severnoi Azii. Problemy i perspektivy (pp. 21-66). Sankt-Peterburg: IIMK RAN.

Sober, E. (1980). Evolution, population thinking, and essentialism. Philosophy of Science, 47, $350-383$

Sobkowiak-Tabaka, I. (2017). Rozwój społecznośti Federmesser na Nizinie Środkowoeuropejskiej. Poznań: Wydawnictwo Instytutu Archeologii i Etnologii Polskiej Akademii Nauk.

Sobkowiak-Tabaka, I., \& Winkler, Katja. (2017). The Ahrensburgian and the Swiderian in the area around the middle Oder River: reflections on similarities and differences. Quartär, 64, 217-240.

Soffer, O., Adovasio, J. M., \& Hyland, D. C. (2000). The "Venus" figurines: Textiles, basketry, gender, and status in the Upper Paleolithic. Current Anthropology, 41, 511537.

Sørensen, M. L. S. (2014). The archaeological culture concept: Hot or cold understandings. In H. Alexandersson, A. Andreeff \& A. Bünz (Eds.), Med Hjärta Och Hjärna: En Vänbok till Professor Elisabeth Arwill-Nordbladh (pp. 247-258). Gothenburg: Department of Historical Studies, University of Gothenburg.

Soriano, S. (1998). Les microgravettes du Périgordien de Rabier à Lanquais (Dordogne) : analyse technologique fonctionnelle. Gallia préhistoire 40, 75-94. 
Straus, L. G. (2000). A quarter-century of research on the Solutrean of Vasco-Cantabria, Iberia and beyond. Journal of Anthropological Research, 56, 39-58.

Svoboda, J. A. (2007). The Gravettian on the Middle Danube. Paléo, 19, 203-220.

Svoboda, J. (2015). Perspectives on the Upper Palaeolithic in Eurasia: the Case of the Dolní Vestonice-Pavlov Sites. In N. Sanz (Ed.), Human origin sites and the World Heritage Convention in Eurasia, vol. 1 (HEADS 4), pp. 190-204. Paris \& Mexico City: UNESCO.

Svoboda, J. A., \& Novák, M. (2004). Eastern Central Europe after the Upper Pleniglacial: changing points of observation. Archäologisches Korrespondenzblatt, 34, 463-477.

Tallavaara, M., Luoto, M., Korhonen, N., Järvinen, H., \& Seppä, H. (2015). Human population dynamics in Europe over the Last Glacial Maximum. Proceedings of the National Academy of Sciences, 112, 8232-8237.

Tarasov, L. M. (1979). Gagarinskaia stoianka i eё mesto v paleolite Evropy. Leningrad: Nauka.

Tarassov [Tarasov], L. M. (1971). La double statuette paléolithique de Gagarino. Quartär, $22,157-163$.

Tejero, J.-M. (2016). Spanish Aurignacian projectile points: An example of the first European Paleolithic hunting weapons in osseous materials. In M. Langley (Ed.), Osseous projectile weaponry (pp. 55-69). Dordrecht: Springer.

Teyssandier, N., \& Zilhão, J. (2018). On the entity and antiquity of the Aurignacian at Willendorf (Austria): Implications for modern human emergence in Europe. Journal of Paleolithic Archaeology, 1, 107-138. 
Teyssandier, N., Bon, F., \& Bordes, J.-G. (2010). Within projectile range: some thoughts on the appearance of the Aurignacian in Europe. Journal of Anthropological Research, 66, 209-229.

Tixier, J. (2012). A method for the study of stone tools : guidelines based on the work of J. Tixier $=$ Méthode pour l'étude des outillages lithiques: notice sur les travaux scientifiques de J. Tixier. Luxembourg: Musée National d'Histoire et d'Art/Centre National de Recherche Archeologique.Tomášková, S. (2003). Nationalism, local histories and the making of data in archaeology. Journal of the Royal Anthropological Institute, 9, 485-507.

Tsanova, T., Zwyns, N., Eizenberg, L., Teyssandier, N., Le Brun-Ricalens, F., \& Otte, M. (2012). Le plus petit dénominateur commun: réflexion sur la variabilité des ensembles lamellaires du Paléolithique supérieur ancien d'Eurasie. Un bilan autour des exemples de Kozarnika (Est des Balkans) et Yafteh (Zagros central). L'Anthropologie, 116, 469-509.

Vander Linden, M., \& Roberts, B. W. (2011). A tale of two countries: Contrasting archaeological culture history in British and French archaeology. In B. W. Roberts \& M. Vander Linden (Eds.), Investigating archaeological cultures: Material culture, variability, and transmission (pp. 23-40). New York: Springer-Verlag.

Vanhaeren, M., \& d'Errico, F. (2006). Aurignacian ethno-linguistic geography of Europe revealed by personal ornaments. Journal of Archaeological Science, 33, 1105-1128.

Van Oyen, A. (2015). Actor-Network Theory's take on archaeological types: Becoming, material agency and historical explanation. Cambridge Archaeological Journal, 25, $63-78$. 
Van Oyen, A. (2017). Material culture and mobility: A brief history of archaeological thought. In C. Heitz \& R. Stapfer (Eds.), Mobility and pottery production: Archaeological \& anthropological perspectives (pp. 53-65). Leiden: Sidestone Press.

Verpoorte, A. (2009). Limiting factors on early modern human dispersals: The human biogeography of late Pleniglacial Europe. Quaternary International, 201, 77-85.

White, R. (1997). Perspectives technologiques sur la «double statuette » de Gagarino. Techne, 5, 6-16.

Wierer, U. (2013). Variability and standardization: The early Gravettian lithic complex of Grotta Paglicci, Southern Italy. Quaternary International, 288, 215-238.

Wiessner, P. (1983). Style and social information in Kalahari San projectile points. American Antiquity, 48, 253-276.

Wiessner, P. (1985). Style or isochrestic variation? A reply to Sackett. American Antiquity, $50,160-166$.

Wilczyński, J. (2015). Lithic artefacts. In J. Wilczyński (Ed.), A Gravettian site in southern Poland: Jaksice II (pp. 33-62). Krakow: ISEA PAS.

Wilczyński, J., Wojtal, P., Łanczont, M., Mroczek, P., Sobieraj, D., \& Fedorowicz, S. (2015). Loess, flints and bones: Multidisciplinary research at Jaksice II Gravettian site (southern Poland). Quaternary International, 359-60: 114-30.

Will, M., Mackay, A. (this volume). A matter of time and space: How frequent is convergence in lithic technology in the African archaeological record over the last 300 
kyr? In: H. Groucutt (Ed.), Culture History and Convergent Evolution: Can we Detect Populations in Prehistory? (pp. x). Springer, Cham, Switzerland.

Wobst, H. M. (1977). Stylistic behavior and information exchange. In C. E. Cleland (Ed.), For the director: Research essays in honor of James B. Griffin (Anthropological Papers 61) (pp. 317-342). Ann Arbor: University of Michigan Museum of Anthropology.

Wojtal, P., Wilczyński, J., Wertz, K., \& Svoboda, J. A. (2018). The scene of a spectacular feast (part II): Animal remains from Dolní Věstonice II, the Czech Republic. Quaternary International, 466 B, 194-211.

Yanevich, A. (2014). Les occupations gravettiennes de Buran-Kaya III (Crimée) : contexte archéologique. L'anthropologie, 118, 554-566.

Zheltova, M. N. (2015). Kostenki 4: Gravettian of the east - not Eastern Gravettian. Quaternary International, 359-360, 362-371.

Zilhão, J., \& d'Errico, F. (2003). The chronology of the Aurignacian and Transitional technocomplexes. Where do we stand? In J. Zilhão \& F. d'Errico (Eds.), The chronology of the Aurignacian and of the transitional technocomplexes: Dating, stratigraphies, cultural implications. (Trabalhos de Arqueologia 33) (pp. 313-349). Lisbon: Instituto Português de Arqueologia. 